\title{
Passive Sampling of Aromatic Hydrocarbons Toluene, Xylene and Ethylbenzene Using Activated Carbon Fabric in Ambient Air of Tehran
}

\author{
Razieh Salehi ${ }^{1}$, Fatemeh Dadashian ${ }^{2 *}$, Mohammad Abedi ${ }^{3}$ \\ 1. PhD Student, Department of Textile Engineering, Amirkabir University of Technology \\ 2. Associate professor, Department of Textile Engineering, Amirkabir University of Technology, Environmental \\ Research Center of Amirkabir University of Technology, \\ 3. Associate professor, Department of Chemical Technologies, Iranian Research Organization for Science and \\ Technology (IROST) \\ *E-mail: dadashia@aut.ac.ir
}

Received: 7 Oct 2018 ; Accepted: 7 Dec 2018

\begin{abstract}
Background and Objectives: Air pollution is one of the most important environmental problems in large cities. Aromatic hydrocarbons as volatile organic compounds (VOCs) have been listed in Hazardous Air Pollutants (HAPs) by Environmental Protection Agencies (EPA). The aim of this study is Passive sampling and determination of aromatic hydrocarbons (AHs) toluene, xylene and ethylbenzene using activated carbon fabric in ambient air of Tehran

Methods: Activated carbon fabric (ACF) was used as adsorbent for adsorption of aromatic hydrocarbons. The chemical specifications of activated carbon fabric such as specific surface area and pores volume were determined by nitrogen adsorption isotherm (BET method), the microscopic images by scanning electron microscopy (SEM) and surface functional groups by X-ray Photoelectron Spectroscopy (XPS). Air sampling was achieved by passive samplers equipped with activated carbon fabric in cylindrical holders at 8 different stations of Tehran. Gas chromatography mass spectrometry (GC-MS) was used for determination of Toluene, Ethylbenzene, and Xylene after extraction in $\mathrm{CH}_{2} \mathrm{Cl}_{2}$.

Results: The results showed activated carbon fabric is an efficient adsorbent for passive sampling of aromatic hydrocarbons and at different stations the concentrations of Toluene, Ethylbenzene, and Xylenes were determined. The results indicated that Javadiyeh station (Region 17) and Imam Khomeini station (Region 10) were polluted than other stations, whereas at Chitgar station (Region 22), Sattari station (Region 5) and Tehran pars station (Region 8) had lower concentrations of AHs. The good correlation between carbon monoxide and aromatic hydrocarbons concentrations in each sampling station showed they have similar source of emission (cars). The concentration of these pollutants is influenced by topography, wind direction and speed and the number of car passing through different stations.

Conclusion: As the concentrations of aromatic hydrocarbons in ambient air are low using AFC in passive sampler is an efficient method for sampling and adsorption of $\mathrm{AHs}$ and then their determination. For this purpose it is necessary to exist special functional groups and especially oxygen containing fuctional groups on the surface of carbon fabric.
\end{abstract}

Keywords: Passive sampling, Activated carbon fabric, Aromatic hydrocarbons, Toluene and Xylene 


\title{
استفاده از روش نمونه بردارى غيرفعال با منسوج كرينى براى اندازهزيرى هيدروكرينهاى آروماتيك تولوئن، زايلن و اتيل بنزن در هواى شهر تهران
}

\author{
راضيه صالحى'، فاطمه داداشيان؟"، محمد عابدى" \\ ' دانشجوى دكترى مهندسى نساجى، دانشكده مهندسى نساجى، دانشگاه صنعتى اميركبير تهران، ايران

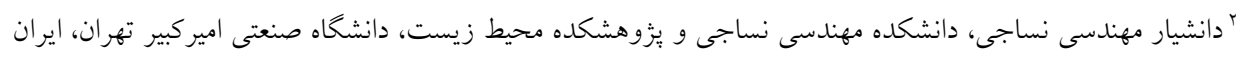

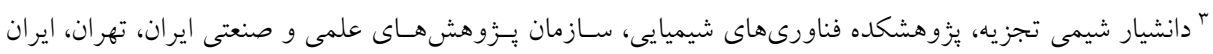

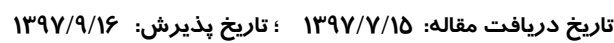

\section{جكيدم}

زمينه و هدف: آلودكى هوا يكى از مهرترين مسائل زيست محيطى شهرهاى بزرك است. هيدروكربنهاى آروماتيك بـهـ

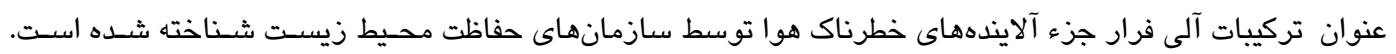

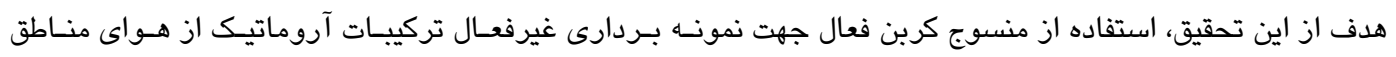
مختلف شهر تهران و اندازهكيرى آنها است.

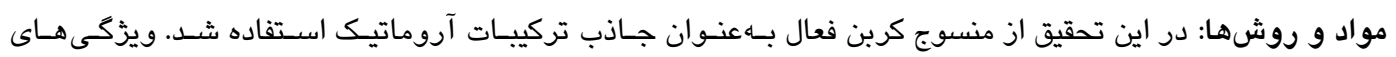

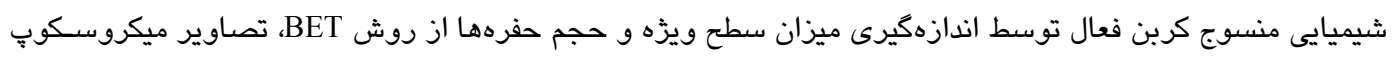

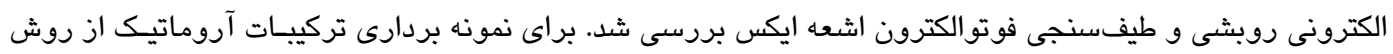

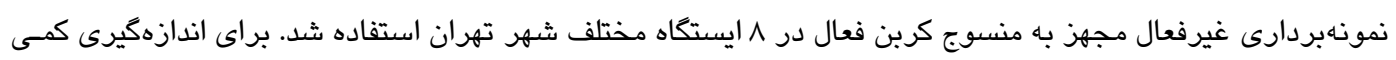

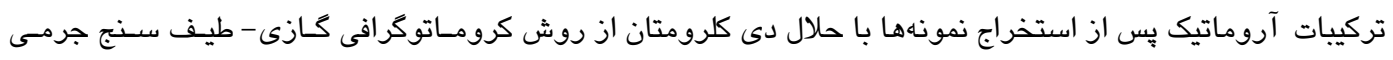
استفاده شد.

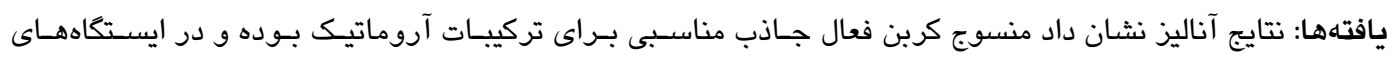

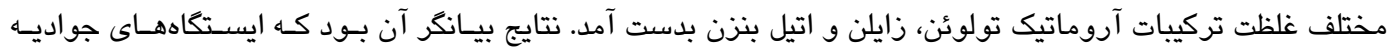

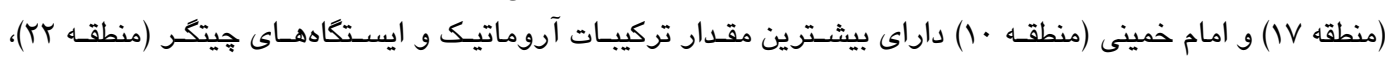

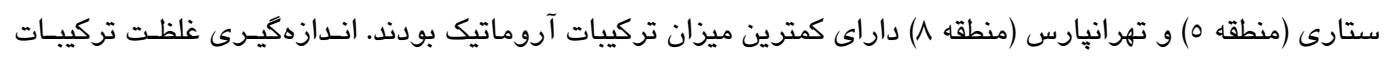

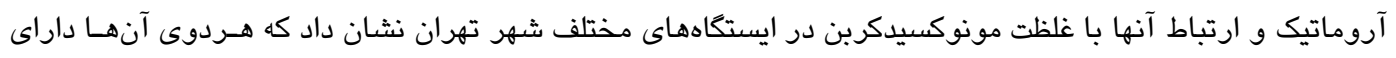

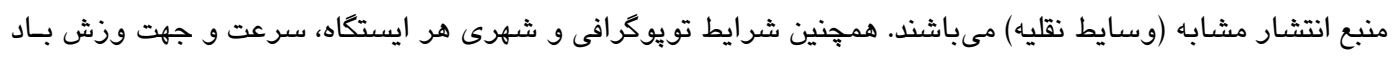

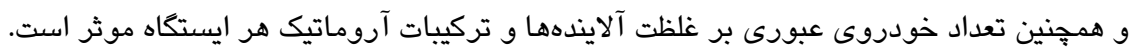

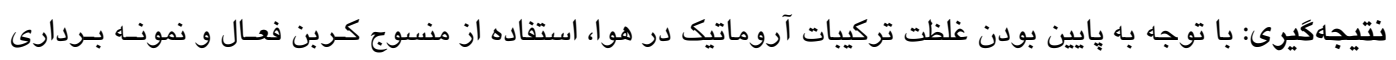

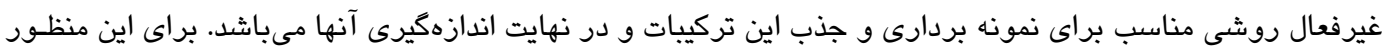

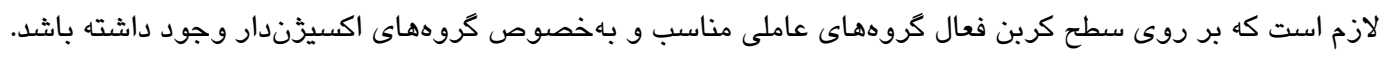

كلمات كليدى: نمونه بردارى غيرفعال، منسوج كربن فعال، هيدروكربنهاى آروماتيك، تولوئن و زايلن 
صنعتى از قبيل فرآيندهاى يتروشيمى، نخهدارى و توزيع رنخ

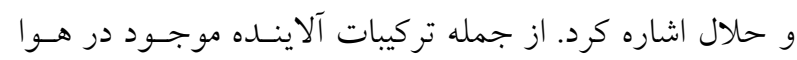

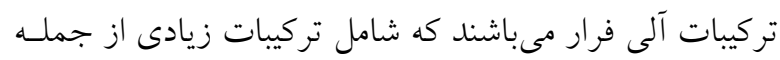

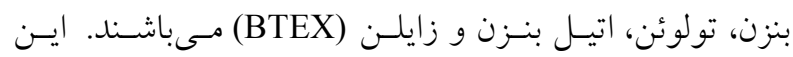

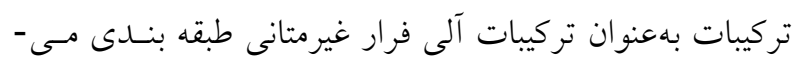

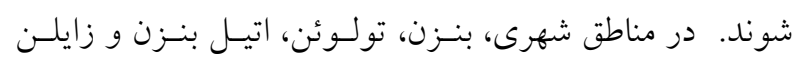

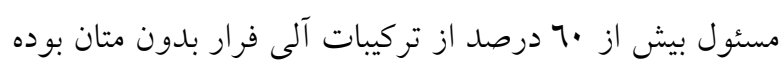

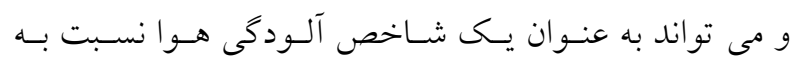

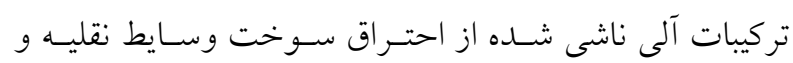

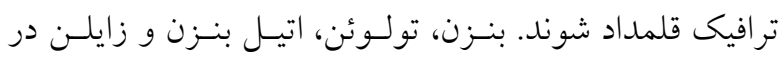

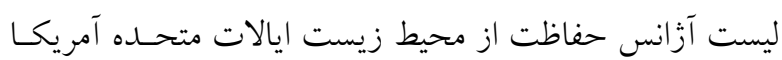

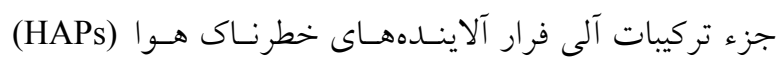
آورده شـــه اسـت، همجنـين در (hazardous air pollutants) ليست آزانسس محسيط زيسـت ارويـا نيـز در رده مــواد بسـيار

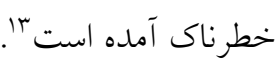

در مطالعه انجام شده توسط صـفوى و عليجـانى (1/N00)،

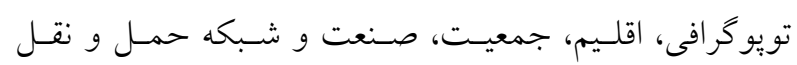

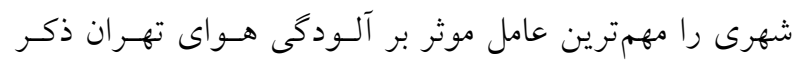

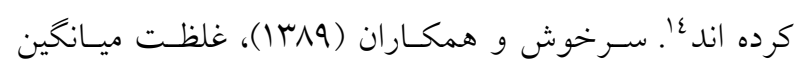

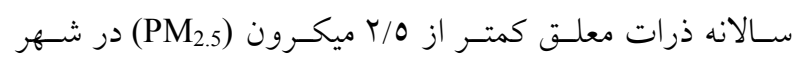

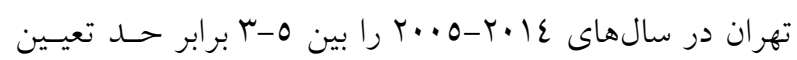

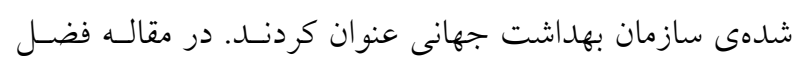

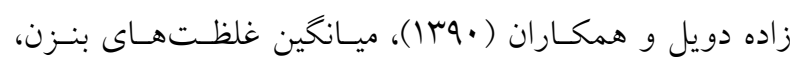

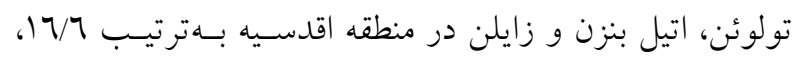

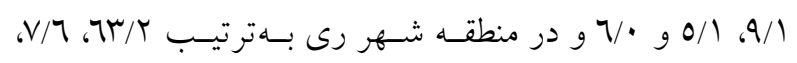


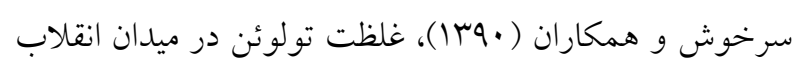

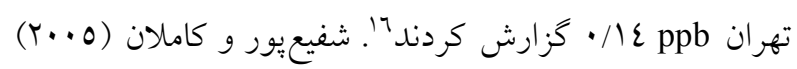

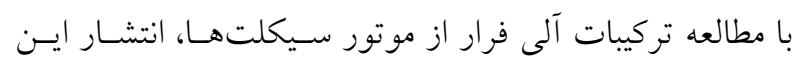

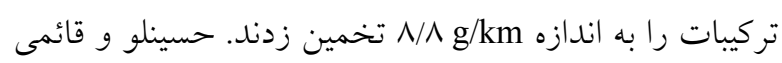

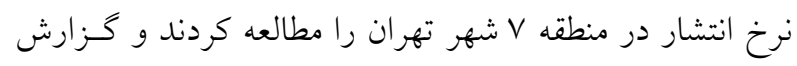

\section{مقدمه}

با افزايش جمعيت و فعاليتهاى روز افـزون بشـر، تعـداد

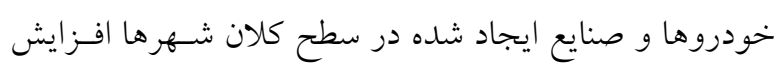

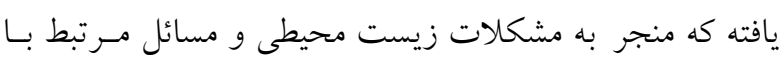

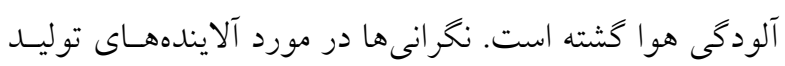
شده و آلودگى هوا به ويزه در حومه شهرهاى شلوغ و صــنايع بزرگ، توجه بيشترى را به خود جلب كرده است. شهر تهـران با وجود وسايل نقليه موتورى، نيرو كاهها و صنايع متعدد و هم جنين موقعيت جغرافيايى خود، بهعنوان يكسى از آلـودهتـرين كلانشهرهاى جهان شناخته شده است، اين مسئله باعث شـده

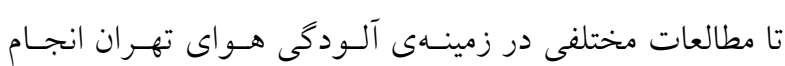
شود ا.

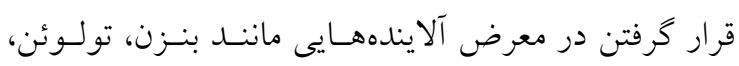

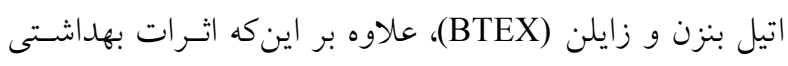

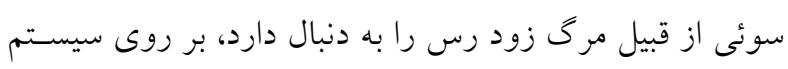

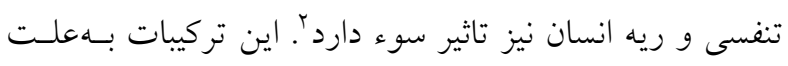

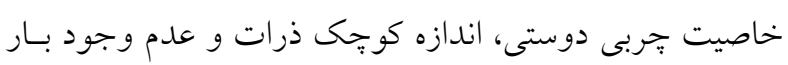

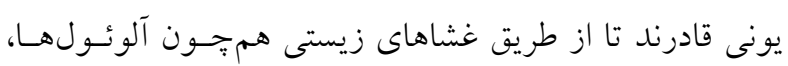

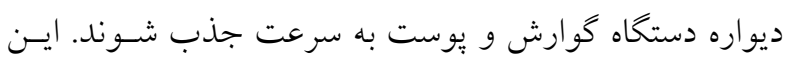

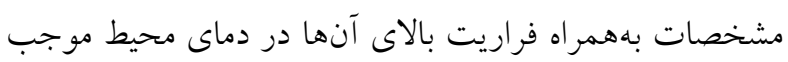

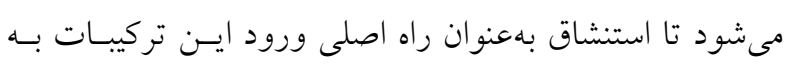

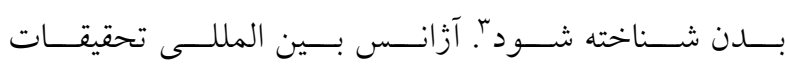

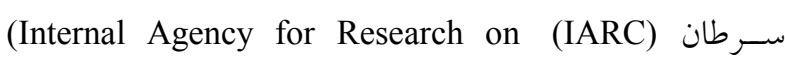
بنزن را به عنوان يكى عامـل سـرطانى شـــيد و اتيـل

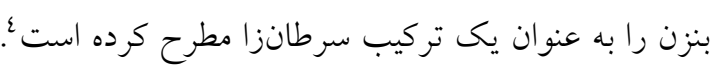

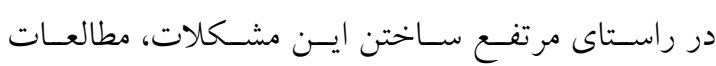

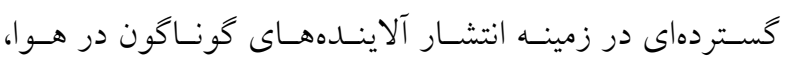

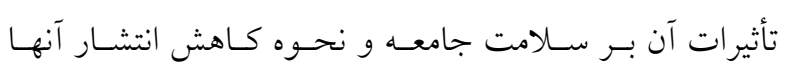

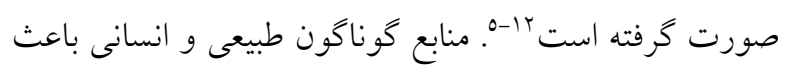

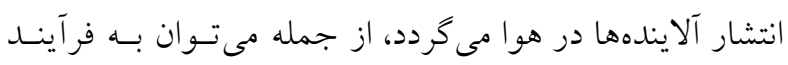

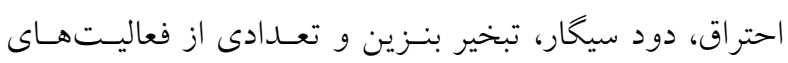


مطلوبتر، تحقيقات در اين زمينه ادامه دارد.

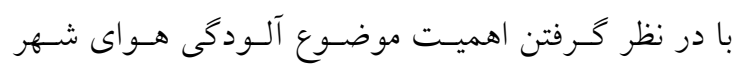

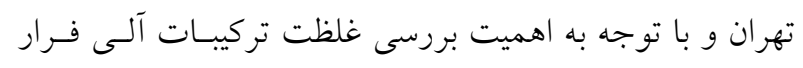

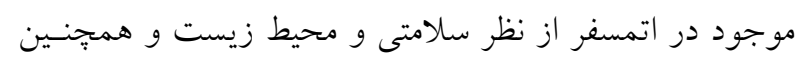
توسعه دانش جاذببهاى غيرفعال براى نمونهبردارى تركيبـات

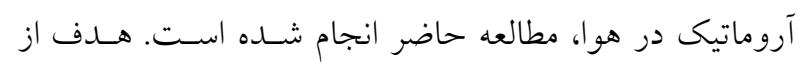

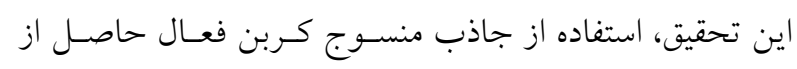

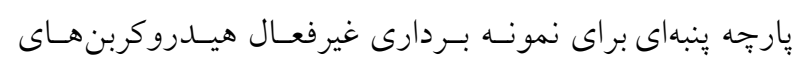

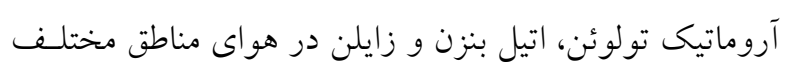

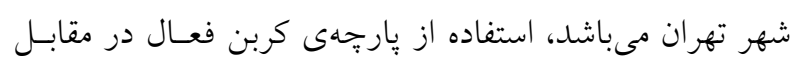

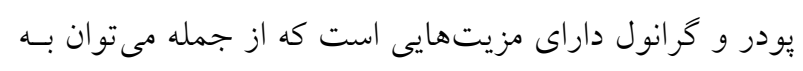

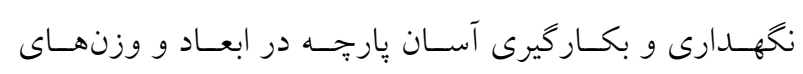

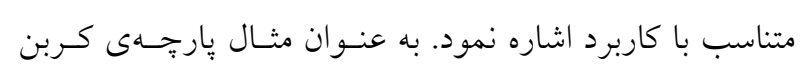

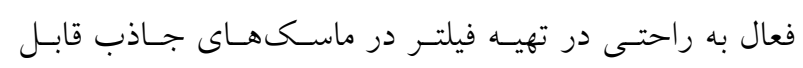

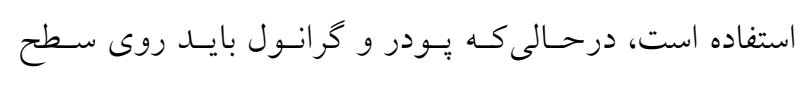

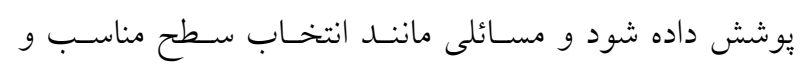
مر احل يوشش مورد نياز است كه موجب هزينسه بيشـتر توليسـ

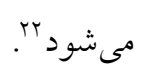

\section{مواد و روشها} ويزگى سنجى جاذب منسوج كرين فعال

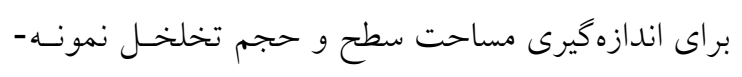

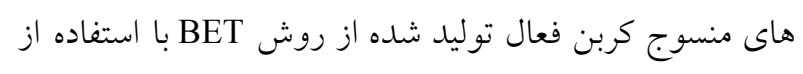

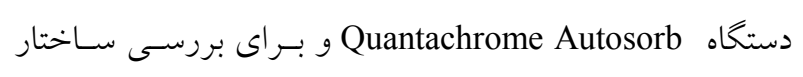

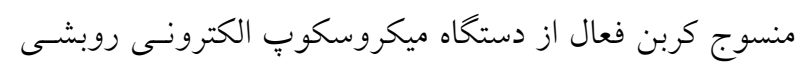

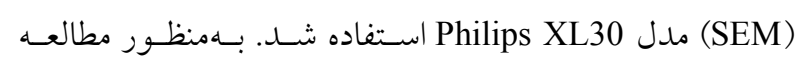

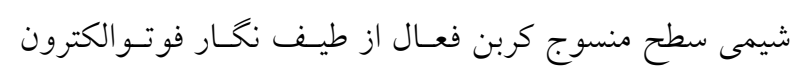

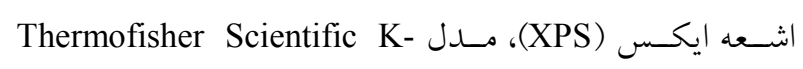
Alpha
كردند كه اتومبيـلهـا عامـل انتشـار كازهـاى فـرار بـه مقــار

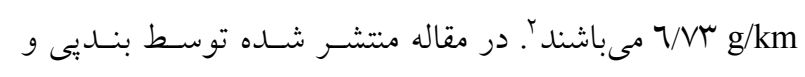

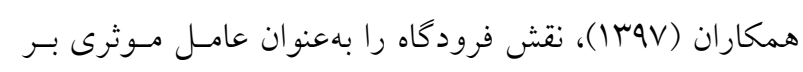

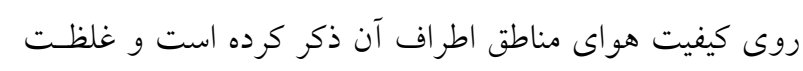

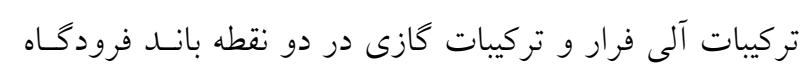

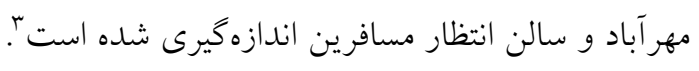

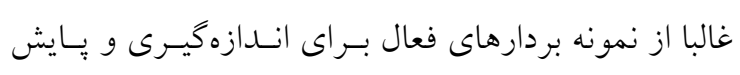

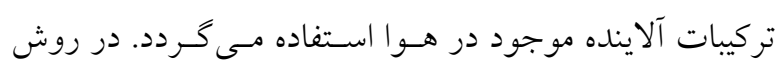

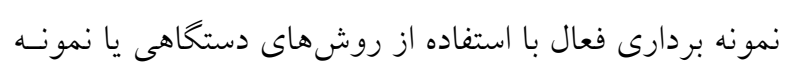

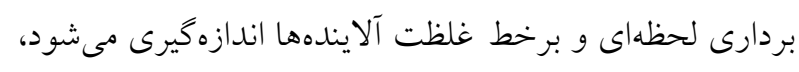

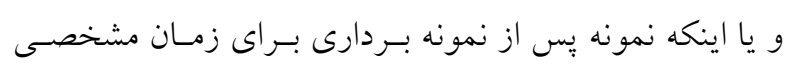

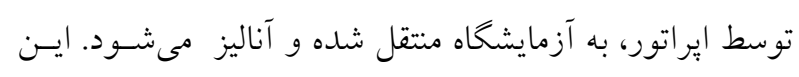

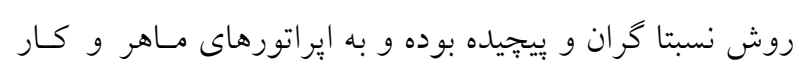

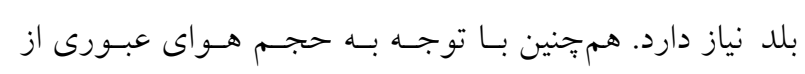

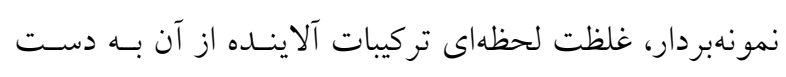

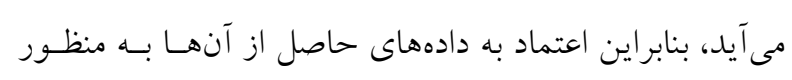

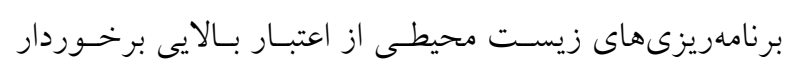

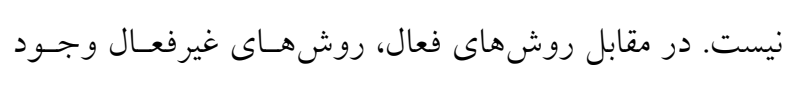

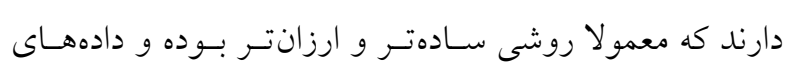

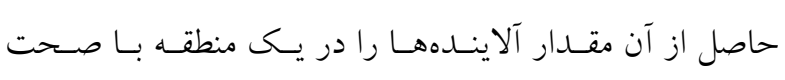

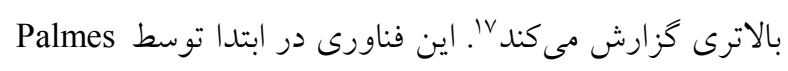

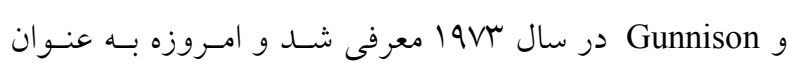

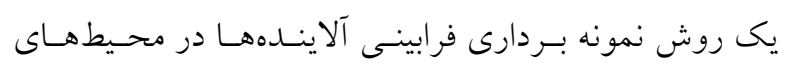

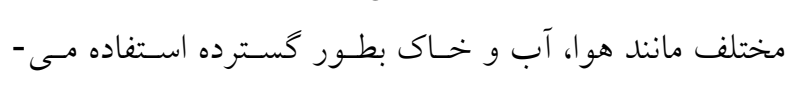
شود'.

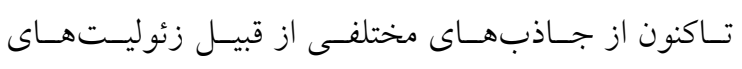

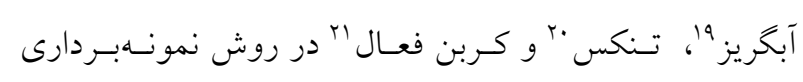

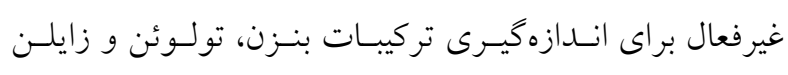

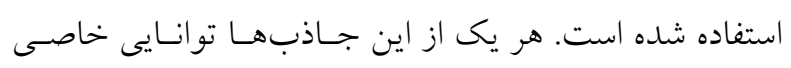

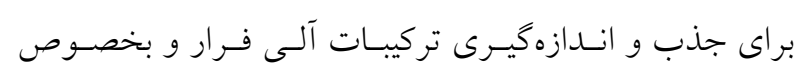

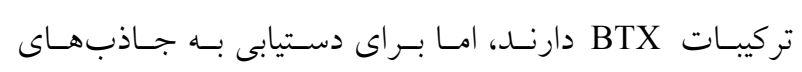


استفاده از روش نمونه بردارى غيرفعال با منسوج كربنى براى اندازهكيرى هيدروكربنهاى آروماتيك تولوئن، زايلن و اتيل بنزن در هواى شهر تهران

محاسبه گرديد. شرايط دستخاه كروماتوگرافى كازى براى آناليز

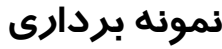

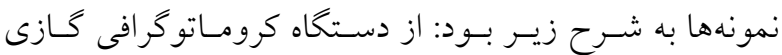
شركت Varian مدل CP-3800 و مجهز بـه سـتون كـاييلارى VF-5ms و طول •7 متر با قطر داخلى 0/ • ميلىمتـر و قطر

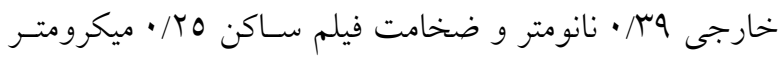
استفاده شد. آشكارساز FID در دماى •ro درجه سانتى گراد و سيستم تزريق Spiltless با جريان كاز اميلىليتـر بـر دقيقهـ و ميزان تزريق ا ميكروليتر اسـفاده شـــ. بــاى انجـام آنـاليز از

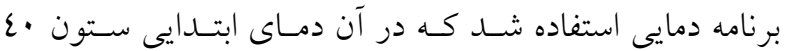
درجه سانتى گراد به مدت ع دقيقه بود كـه بـا شـيب ^ درجــه

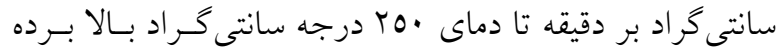

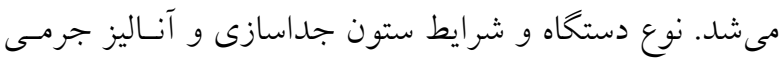
دستكاه GC-MS در جدول اكزارش شده است.

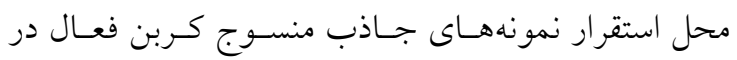
مناطق مختلف تهـران و ايستخاههـاى سـنجش آلـودگى هـوا

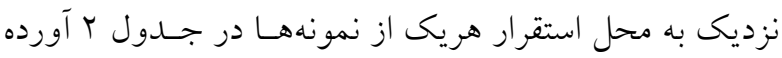

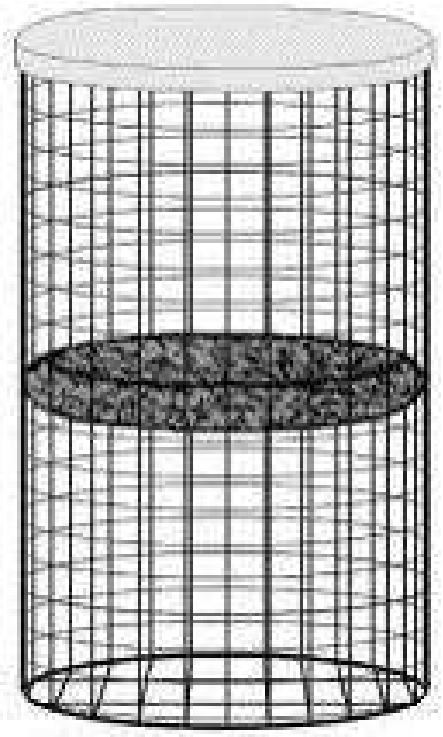

شكل ا: شماتيك نمونهبردارى غيرفعال به همراه جاذب كربن فعال

براى نمونه بــردارى تركيبـات آروماتيـك، از نمونـهـهـ بـردار غيرفعال استفاده شد "r. نمونه بردار غيرفعال شامل يك اسـتوانه يلى اتيلنى به قطر ب/0 سانتى متر و ارتفاع 7 سانتى متر بـود كـهـ. كليه سطوح جانبى آن جهت تبـادل و عبـور آزاد هـوا مشـبك شده بود. مقدار // • گرم منسوج كربن فعال بـهنــوان جـاذب برروى يكى بسـتر تـورى اسـتيل قـرار داده شــهـ و در وسـط استوانه تثبيت شد (شكل (). بــراى نمونـهـ بــردارى، هريـكى از نمونه بردارها به مدت يك هفته (Y (Y-0 آبـان مـاه فضاى آزاد و در مناطق مختلف تهران كه محل استقرار آنها در شكل r نشان داده شده است، قرار گرفت.

\section{آناليز نمونهها}

در بايان نمونه بردارى، هريك از نمونههـا در كيسـه هـاى

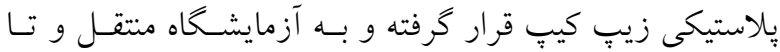

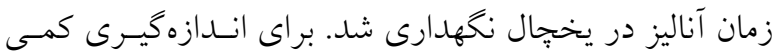
هيدروكربنهـاى آروماتيـك از روش كرومـاتو گرافى گـازى (Gas chromatography-mass استفاده شد. قبل از آناليز هريك از spectrometry (GC-MS)) نمونهها با ا ميلىليتر حـالال دى كلرومتـان استخراج كرديـد. مقدار • بميكروليتر اتيل استات به عنوان استاندارد داخلسى بـهـ هريك از نمونهها اضافه شـلده و سـيس بـه دســاه GC-MS تزريق گرديد عُ. كروماتو گرامهاى تركيبات استاندارد از تزريـق تركيبات تولوئن، زايلن و اتيل بنزن به ترتيب با غلظـت هـاى

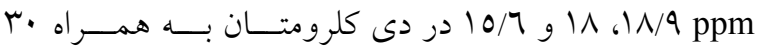
ميكروليتر اتيل استات به عنـوان استاندارد يـس از تزريـق بـــ دستخاه بدست آمدند. نسـبت مسـاحت زيـر بيـك هريـك از اجزاى مورد نظر به مساحت زير بيك استاندارد داخلمى، تعيـين كننده ميزان هر يك از اين تركيبات در نمونه بود. با استفاده از منحنى هاى كاليبراسـيون و كمـك از حافظـه جرمسى دســاه، ميزان غلظت تولوئن، ارتو زايلن، بارا و متا زايلن و اتيل بنـزن 
جدول ا: مشخصات دستكاه و شر ايط ستون جداسازى و آناليز جرمى دستكاه GC-MS براى آناليز تركيبات هيدروكربنهاى آروماتيى

\begin{tabular}{|c|c|}
\hline آشكار ساز كزينشى جرمى: Aligent 5973 network & كروماتو كرافى كازى: Agilent 6890 \\
\hline منبع يون: يونيزاسيون الكترونى & 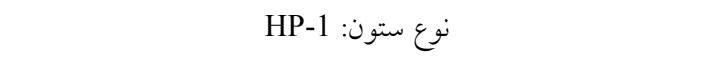 \\
\hline آناليزور جرمى: جهار قطبى & طول ستون: •rمتر \\
\hline انرزى يونيزاسيون: •v الكترون ولت & قطر داخلى ستون: ه广/• ميلىمتر \\
\hline منبع طيف سنج جرمى: •بآ درجه سانتى كراد & ضخامت فيلم ستون: • 10/ • ميكرومتر \\
\hline قطب طيف سنج جرمى: •10 درجه سانتى كراد & 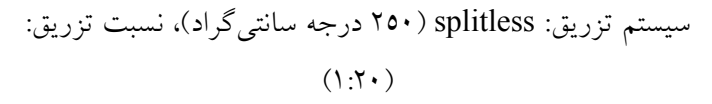 \\
\hline جرم هويش: .00-·ع واحد جرم اتمى & آون ستون: ب درجه سانتى كراد (r دقيقه نحهدارى در اين دما) و \\
\hline & سبس با شيب 0 درجه سانتى گراد بر دقيقه به ..ب درجه سانتى كراد \\
\hline 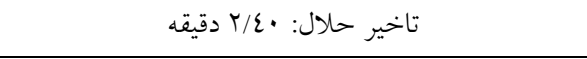 & حجم تزريق: ا ميكروليتر \\
\hline
\end{tabular}

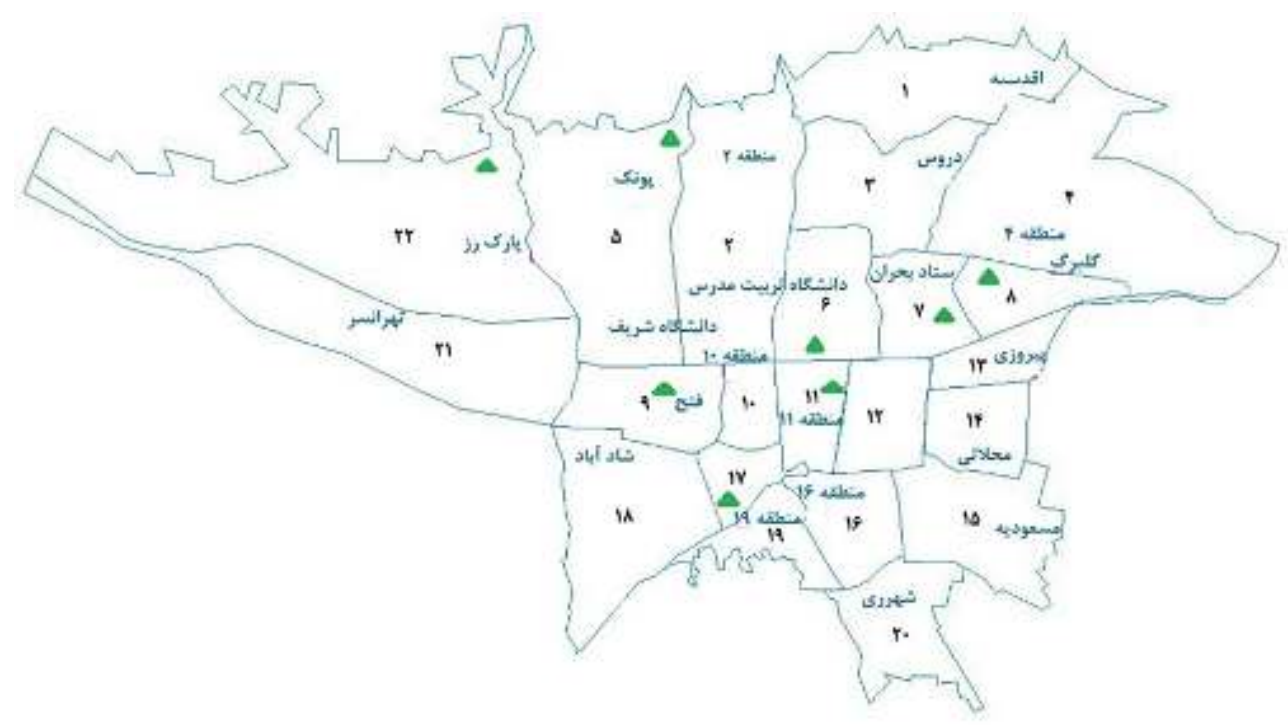

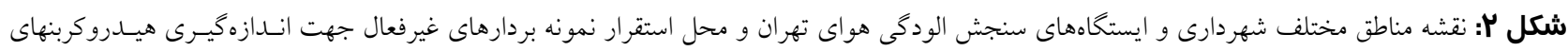
آروماتيك در هواى تهران.

مقايسه شد. ارتباط مقادير شـاخص آلـودخى هـوا و تركيبـات

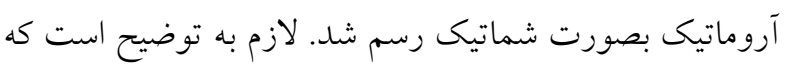

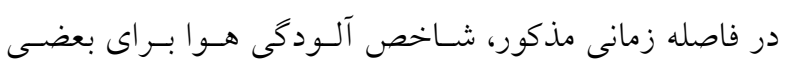

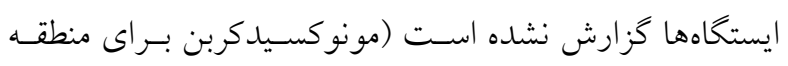

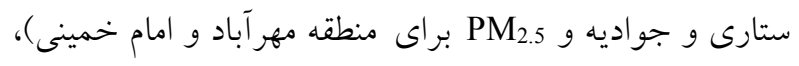

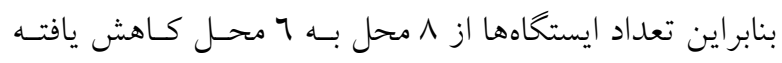
است.
مقسادير شـاخص آلـودذىى هـوا (ميـزان مونو كسـيدكربن و

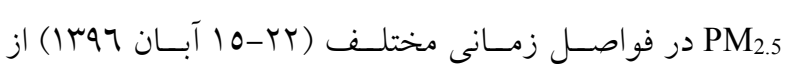

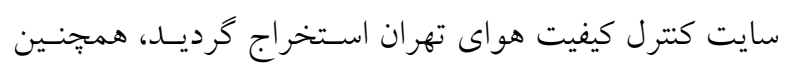

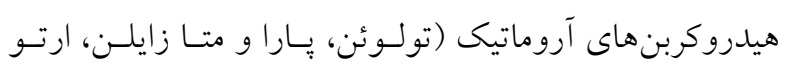

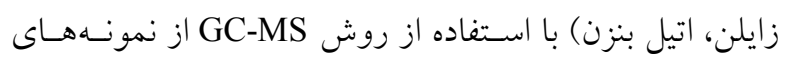

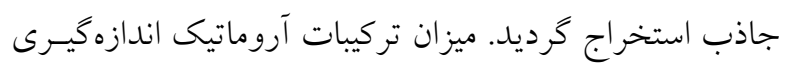
شده با دادهاى مربـوط بـه مقـادير مونو كسيدكربن و 
استفاده از روش نمونه بردارى غيرفعال با منسوج كربنى براى اندازهيرى هيدروكربنهاى آروماتيك تولوئن، زايلن و اتيل بنزن در هواى شهر تهران جدول r: محل استقرار نمونهبردارى غيرفعال و ايستخاههاى بايش هواى نزديك به محل قرار گيرى آنها در شهر تهران براى اندازهيرى تركيبات هيـدروكربنهاى آروماتيك.

\begin{tabular}{|c|c|}
\hline ايستخاههاى بِايش هواى تهران & محل هاى نمونهبردارى غيرفعال \\
\hline كلبرى منطقه 1 & تهر انيارس \\
\hline دانشگاه تهر ان - منطقه 7 & وليعصر \\
\hline يونك - منطقه 0 & 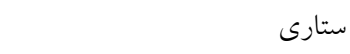 \\
\hline شهرك جشمه - منطقه Tr & جيتخر \\
\hline Vن V V V V & نظام آباد \\
\hline ميدان فتح - منطقه 9 & مهر آباد \\
\hline شهردارى منطقه ·1 & امام خمينى \\
\hline IV بارى سلامت - منطقه & جواديه \\
\hline
\end{tabular}

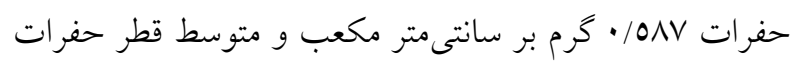

يافتهها

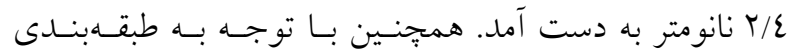
ويزز آيوياك، نمودار جذب و واجذب كاز نيتروزن كـه در شـكل ب آناليز جذب و واجذب نيتروزن منسوج كرين فعال نشان داده شده است، مشابه ايزوترم نوع اول لانخمير مىباشـد نتايج آناليز BET بر روى منسـوج كـربن فعـال نشـان داد، كه براى تركيباتى مزوحفره مناسب است ب0

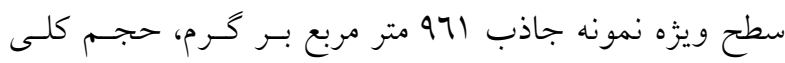

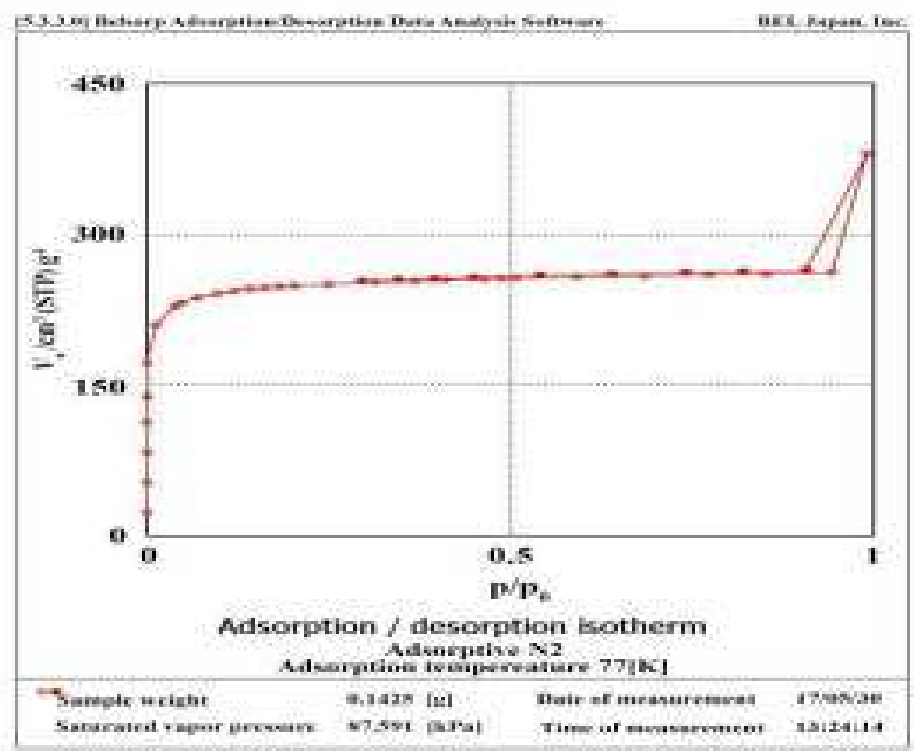

شكل سا: نمودار ايزوترم جذب و واجذب نيتروزن منسوج كربن فعال. 
راضيه صالحى و همكاران

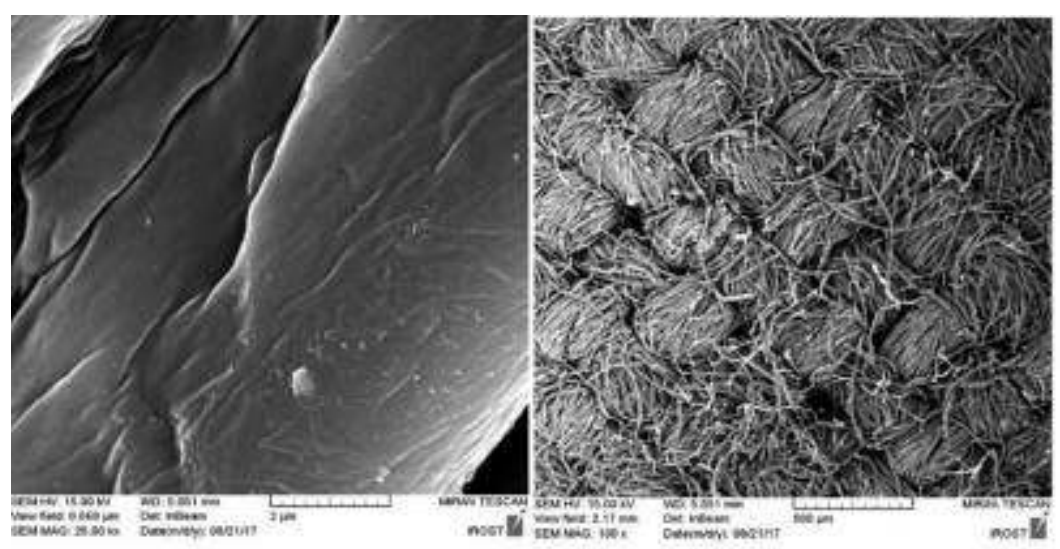

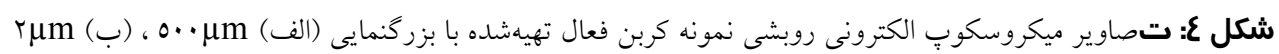

\section{طيـفــ ســنجى فوتــوالكترون يرتــو اشـعه ايكـس}

\section{منسوج كربن فعال}

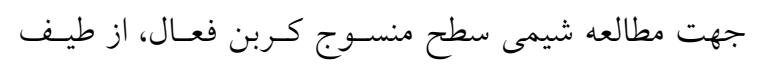

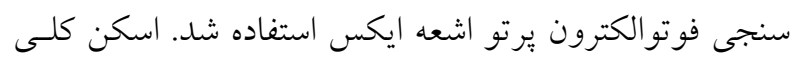

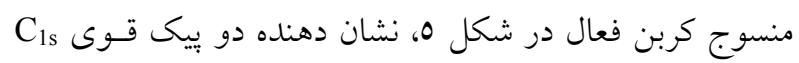

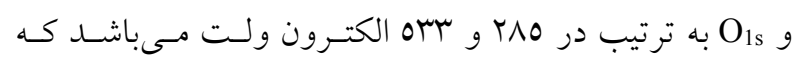

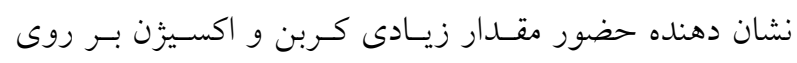

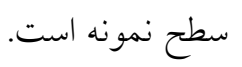

\section{تصاوير ميكروسكو» الكترونـى روبشـى منســوج كربن فعال}

تصاوير ميكروسكوبٍ الكترونى روبشى نمونه كربن فعـال

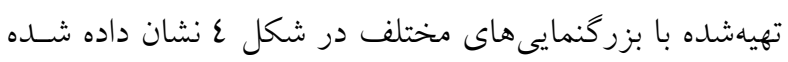
است ، از شكل ع (الف) به خوبى مشاهده مى شود كـه تـراكم

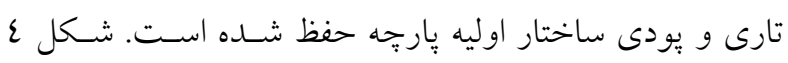

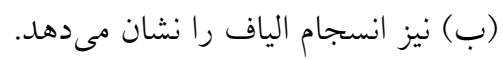

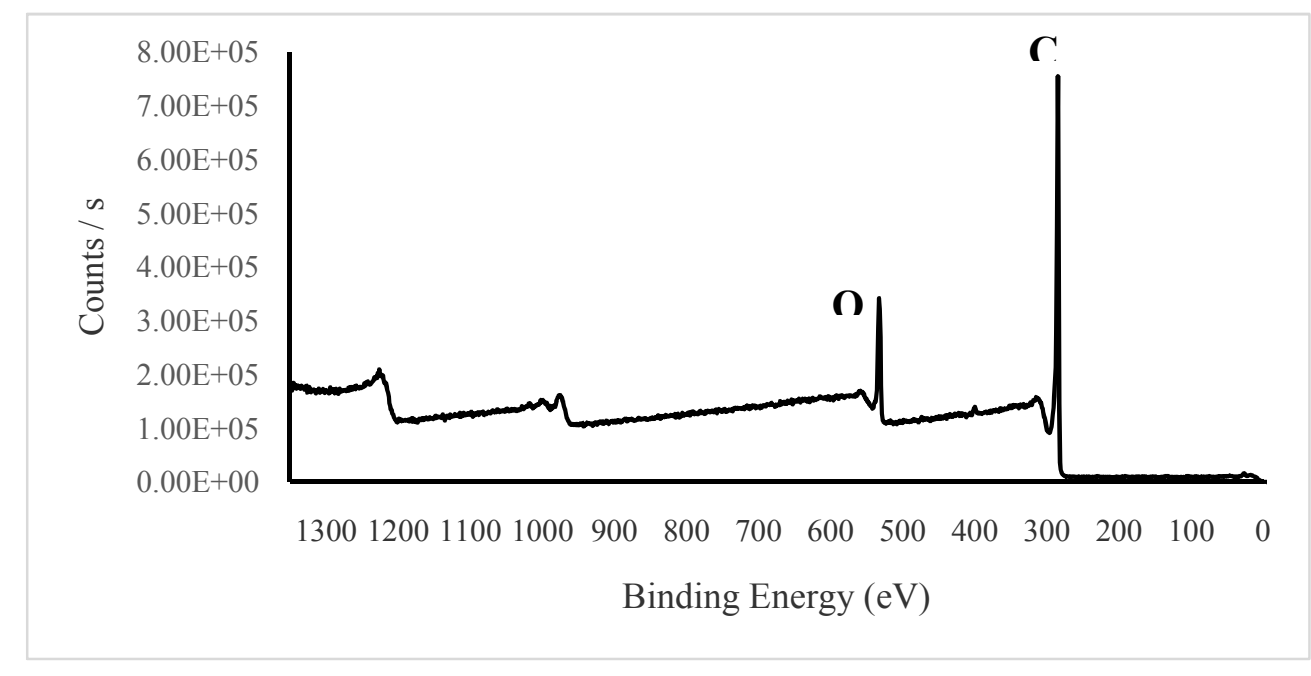

$$
\text { شكل ه: طيف نكارى فوتو الكترون يرتو ايكس منسوج كربن فعال. }
$$

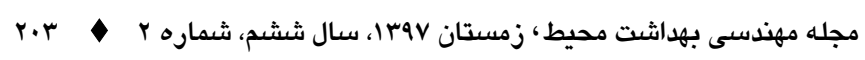


استفاده از روش نمونه بردارى غيرفعال با منسوج كربنى براى اندازهيرى هيدروكربنهاى آروماتيك تولوئن، زايلن و اتيل بنزن در هواى شهر تهران

ارتباط بين تركيبات آلايندههاى هوا و مونوكسيد كربن و ذرات معلق

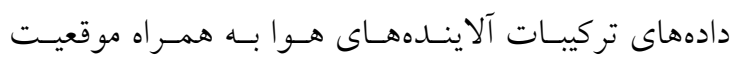

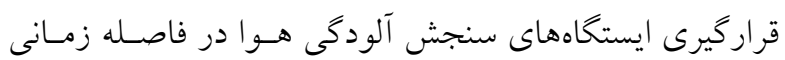

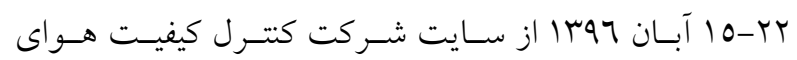

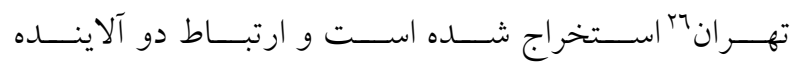

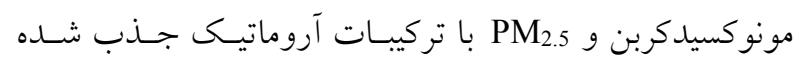

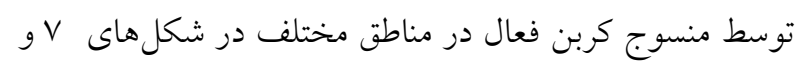

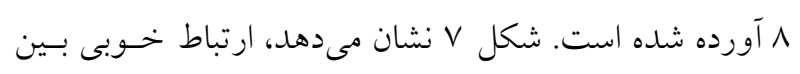

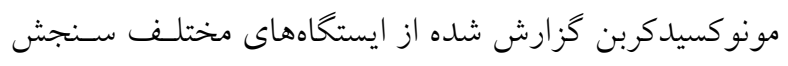

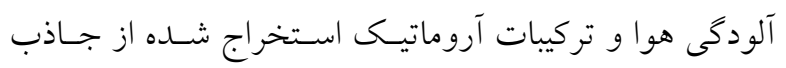

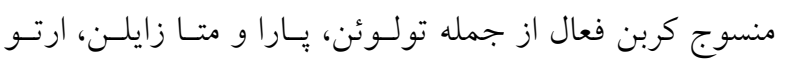

زايلن، اتيل بنزن وجود دارد.
دادههاى بدست آمده از نمونه بردارى غيرفعال در مناطق مختلف تهبران

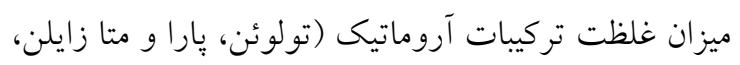

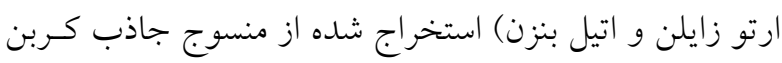

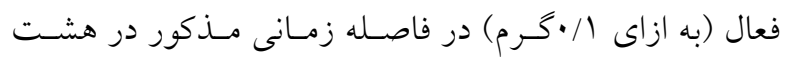

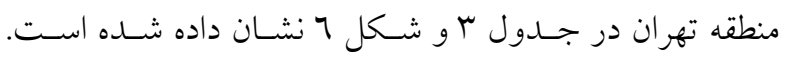

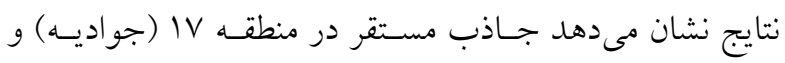

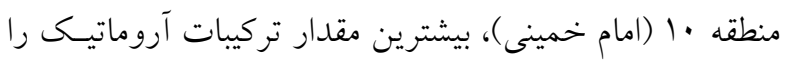

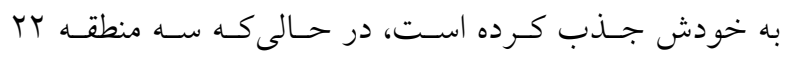

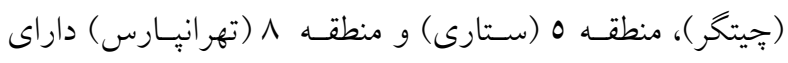

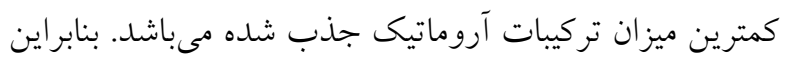

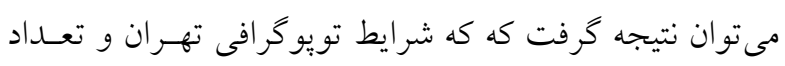
خودروى عبورى، غلظت آلايندهها را تحت تاثير قرار مى دهد.

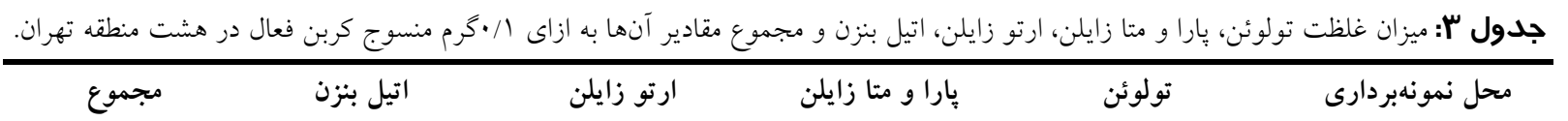

\begin{tabular}{|c|c|c|c|c|c|}
\hline (ميكروگرم) & (ميكروگرم) & (ميكروگرم) & (ميكروگرم) & (ميكرو گرم) & \\
\hline$r q / r$ & $\Gamma / \Gamma \pm \cdot / \Lambda$ & $r / \mu \pm 1 / r$ & $\Lambda / r \pm 1 / 7$ & $1 \varepsilon / r \pm r / 0$ & تهرانِارس \\
\hline ro/s & $r / \Lambda \pm 1 / r$ & $\varepsilon / 1 \pm \cdot / q$ & $9 / \wedge \pm 1 / \Lambda$ & $|N /| \pm r / r$ & وليعصر \\
\hline ro/r & $\varepsilon / 1 \pm 1 / r$ & $\varepsilon / \Lambda \pm 1 / r$ & $1 \cdot / 9 \pm r / \varepsilon$ & $10 / 0 \pm r / 7$ & ستارى \\
\hline$r q / v$ & $\varepsilon / V \pm 1 / 1$ & $O N \pm 1 / V$ & $|r / 0 \pm Y /|$ & $\mid r / \Lambda \pm r / V$ & جيتخر \\
\hline$\varepsilon N / V$ & $O / V \pm I / V$ & $7 / \Lambda \pm 1 / \varepsilon$ & $10 / 2 \pm T / V$ & $r \cdot / \Lambda \pm r / \varepsilon$ & نظام آباد \\
\hline$\pi r / \varepsilon$ & $\wedge / 1 \pm \cdot / q$ & $9 / N \pm 1 / 0$ & $r / / 0 \pm r / r$ & $r \varepsilon / l \pm r / r$ & مهر آباد \\
\hline VV & $\Lambda / \varepsilon \pm 1 / r$ & $9 / 1 \pm 1 / 7$ & $r r / r \pm T / V$ & $r q / 0 \pm r / \tau$ & امام خمينى \\
\hline$|r| / r$ & $17 / 9 \pm 1 / 7$ & $\mid N / r \pm r / r$ & $\varepsilon 1 / \varepsilon \pm r / q$ & $\varepsilon \varepsilon / \Lambda \pm r / r$ & جواديه \\
\hline
\end{tabular}

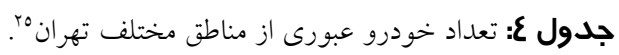

\begin{tabular}{|c|c|c|c|c|c|c|c|c|}
\hline جو اديه & امام خمينى & مهر آباد & نظام آباد & جֶيتگر & ستارى & وليعصر & تهر انيارس & مناطق \\
\hline $90 r \varepsilon 7$ & $\varepsilon r \sum 19$ & IVQTEY & $\varepsilon \varepsilon 7 \varepsilon V$ & TYTEY & or79\& & $7 \pi+9$ & OV乏 79 & تعداد خودرو \\
\hline r & $\checkmark$ & 1 & 7 & $\wedge$ & 0 & r & $\varepsilon$ & رتبه تعداد خودرو عبورى \\
\hline
\end{tabular}


راضيه صالحى و همكاران
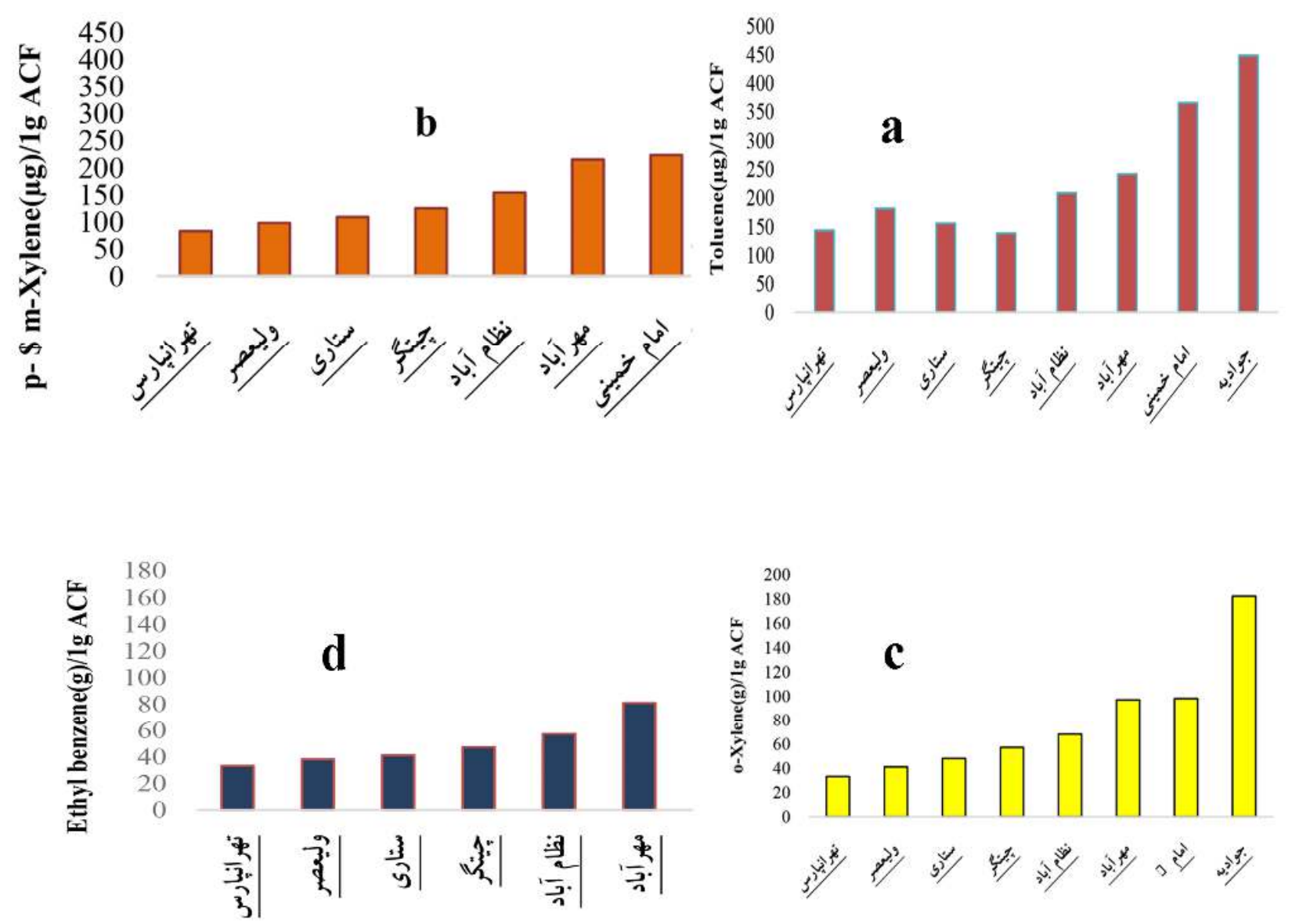

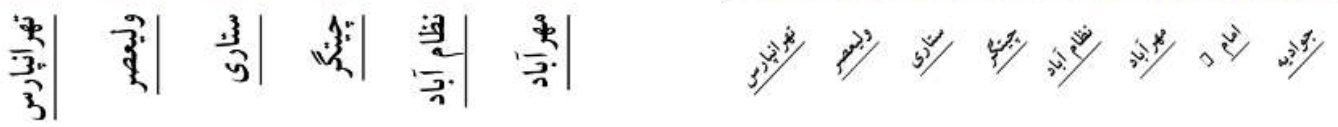

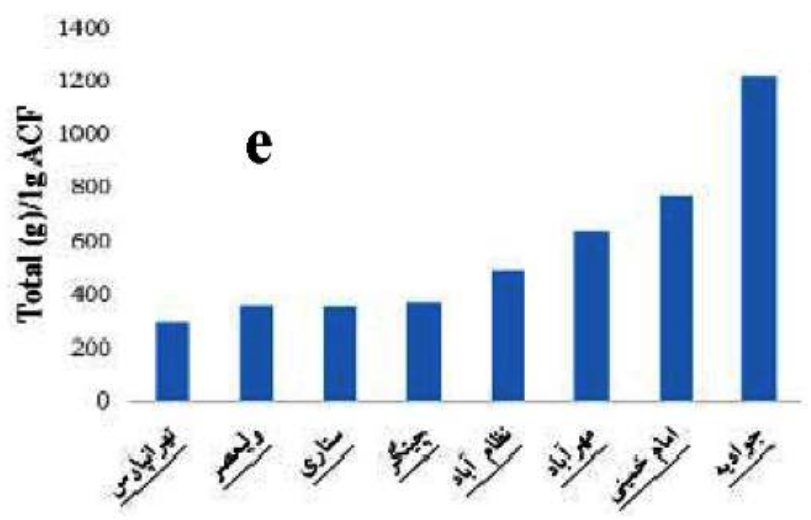

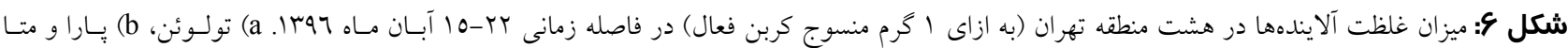

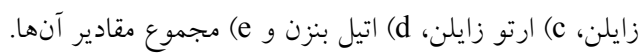



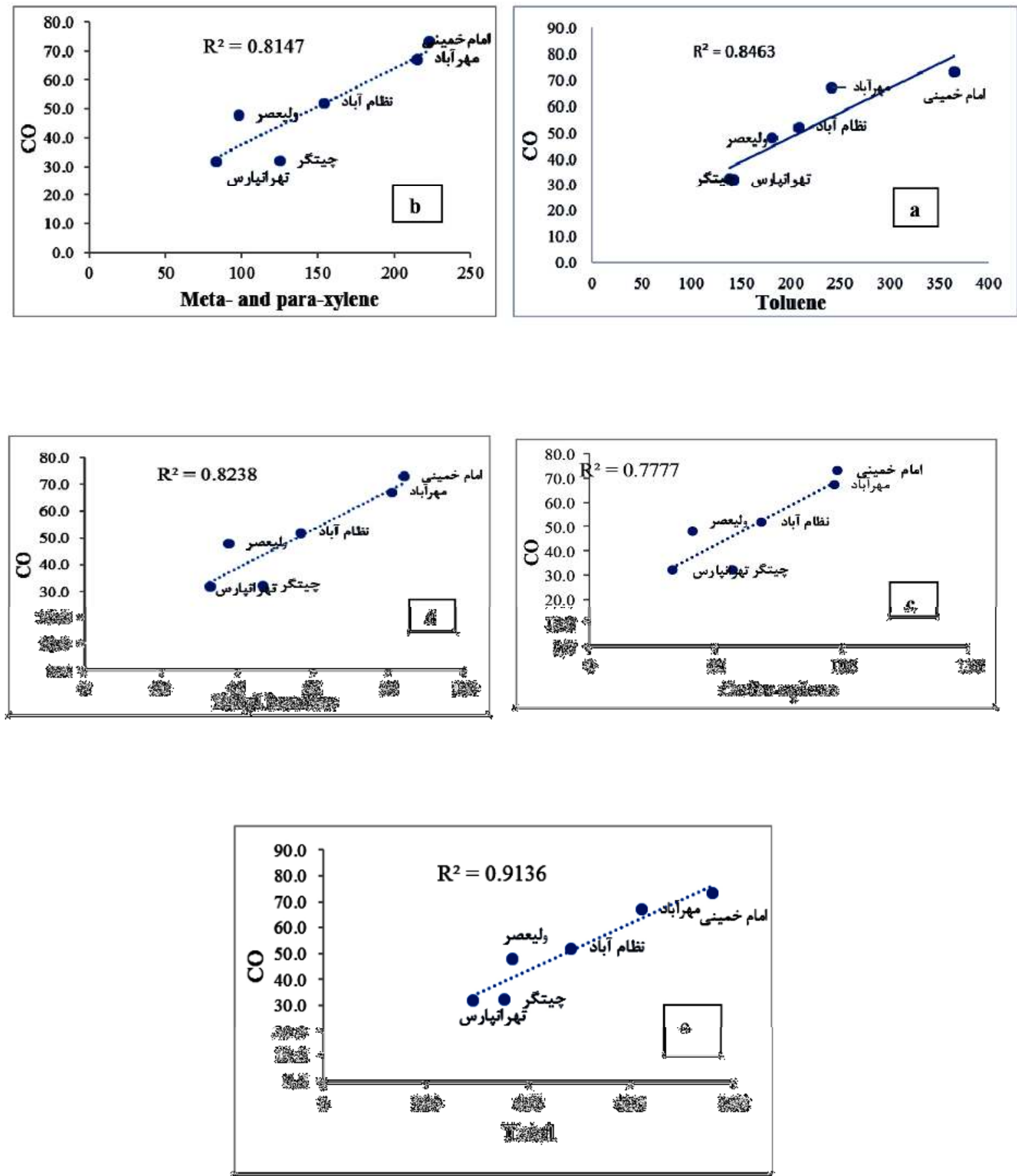

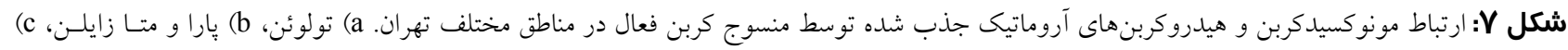

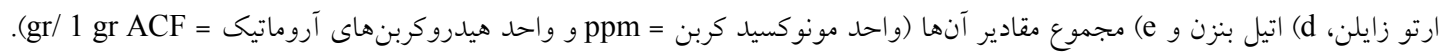


راضيه صسالحى و همكاران
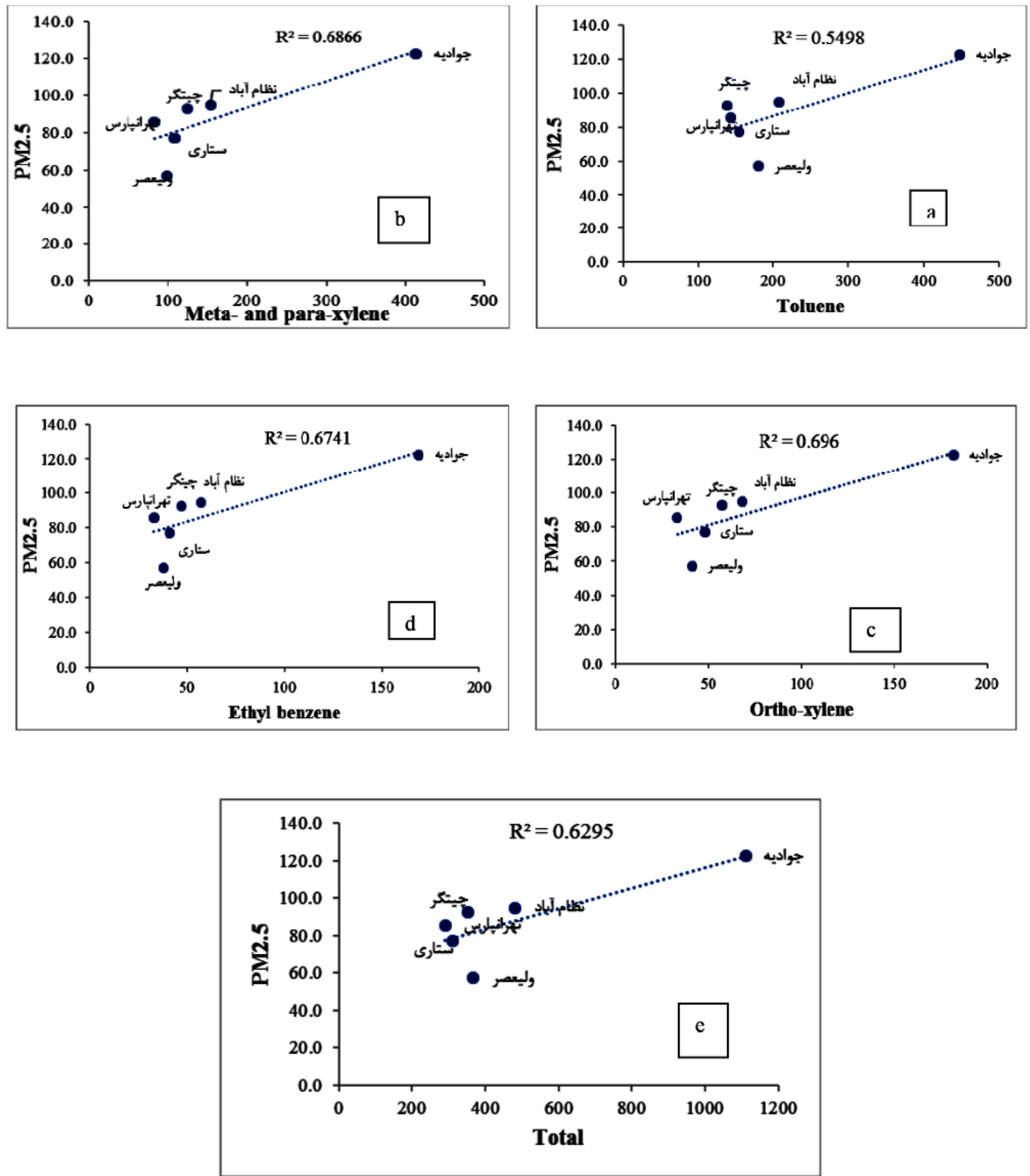

شكل A: ارتباط PM2.5 و هيدروكربنهاى آروماتيكى جذب شده توسط منسوج كربن فعال در مناطق مختلف تهران. a) تولـوئن، b) هـارا و متـا زايلسن، c) ارتـو

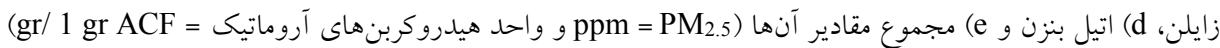


استفاده از روش نمونه بردارى غيرفعال با منسوج كربنى براى اندازهكيرى هيدروكربنهاى آروماتيك تولوئن، زايلن و اتيل بنزن در هواى شهر تهران

بقيه مناطق) را به خود اختصـاص داده اسـت، همجنـين قـرار بحث

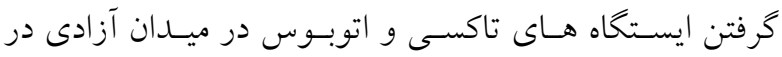

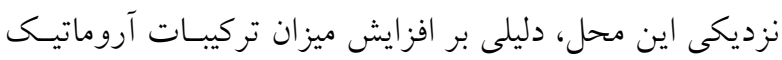
جذب شده توسط جاذب مىباشد. وجود مونوكسيد كربن در اخزوز اتومبيل و ساير وسايل نقليه كه نتيجه سوخت ضعيف و

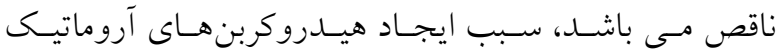

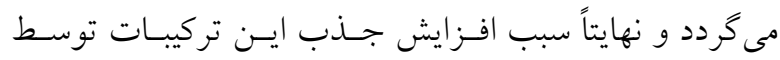
جاذب مستقر در آن منطقه شده اسـت. در مقالـه منتشـر شـده توسط محسنى بنديى و همكاران (IrqV)، بـهـ نقـش فرودكـاه

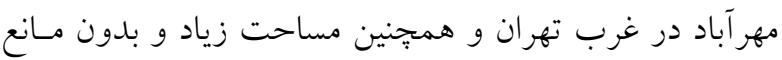
فرودگاه در افزايش آلودخى مناطق اطراف فرودگاه اشاره كـرده

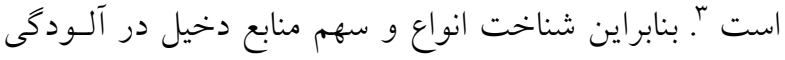

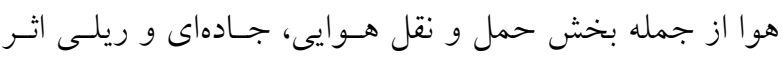

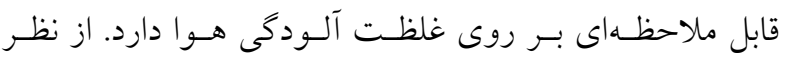

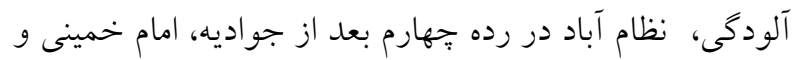

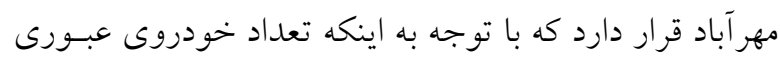

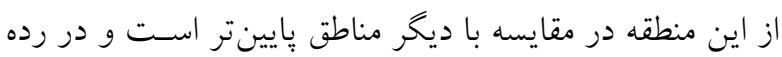

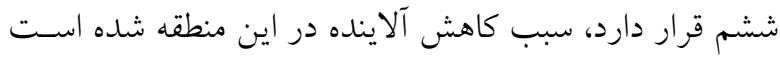

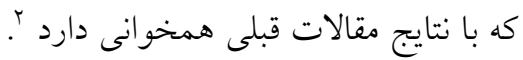

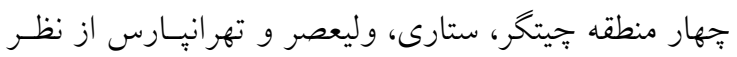

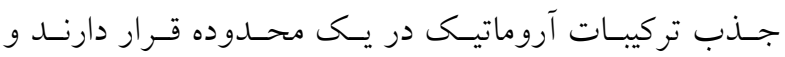
كمترين ميزان جذب آلايندهها را به خـود اختصـاص دادهانــ. جيتخر و ستارى از نظر موقعيت جغر افيايى و با توجه به اينكه

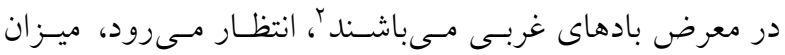
هيدروكربنهاى آروماتيك كمى را توسط جاذب منسوج كربن فعال به خود جذب كند، عامل جاروب كننده هواى تهران بادهاى غربى هستند كه در غرب تهران بهتر از شرق آن عمل مى

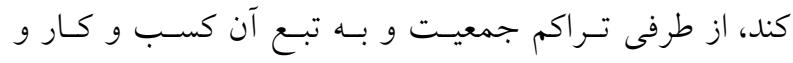

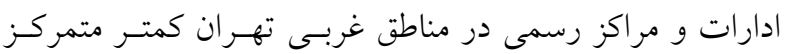

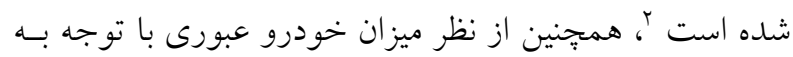

نتايج حاصل از ميزان غلظت تركيبات آروماتيك (تولـوئن،

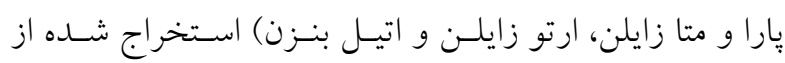

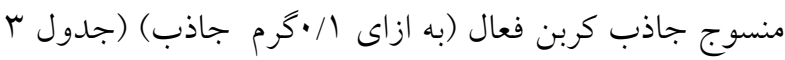

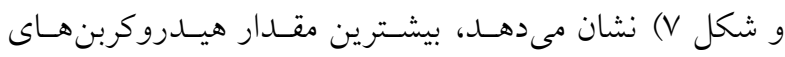

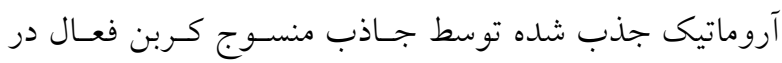

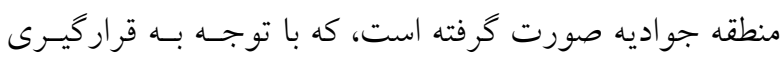

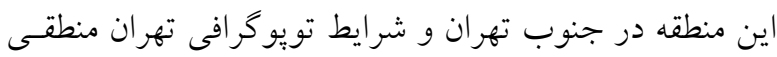

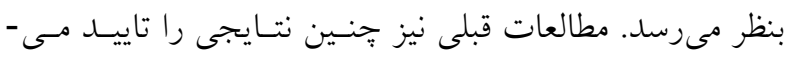
كنند ؟. از نظر تعداد خودروى عبورى نيـز جواديسه در رده دوم

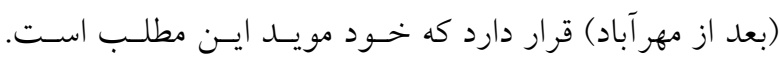

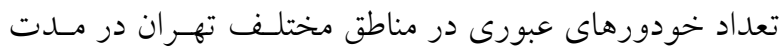
زمان مذكور در جدول ع آورده شده است.

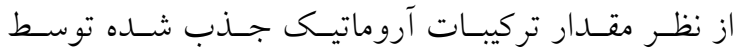
جاذب، منطقه امام خمينى در رده دوم قـرار دارد كـهـ بـددليـل موقعيت جغرافيايى و حجم ترافيك ايـن منطقـهـ مسىباشـد. در

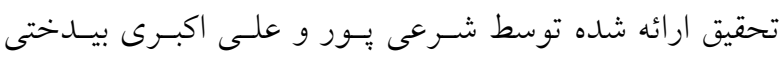

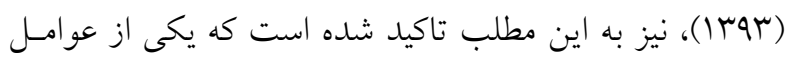

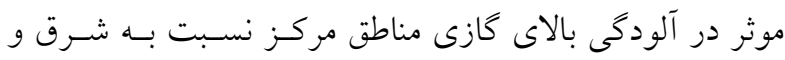

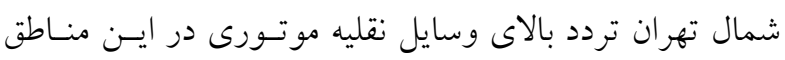

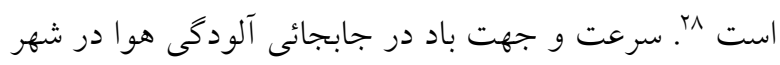

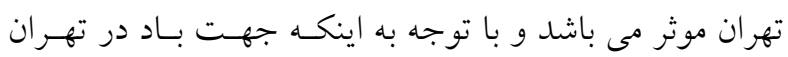

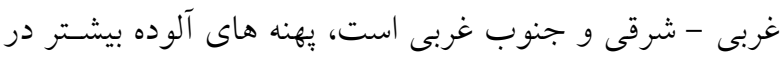

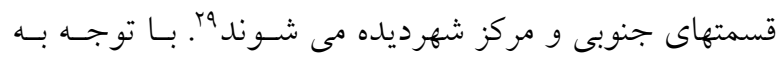

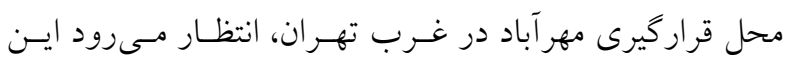

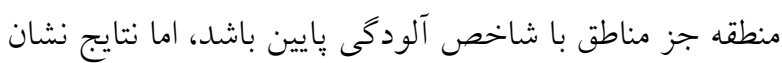

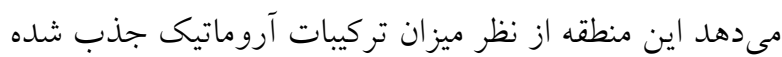
در رده سوم (بعد از جواديه و امام خمينى) مى باشد. مطالعـات

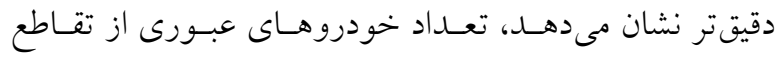
نزديك به اين منطقه بيشترين مقدار (بـا اخـتلاف جشـميكير از 
استخراج تركيبات آروماتيك با حلال جهت اندازه كيرى كمى

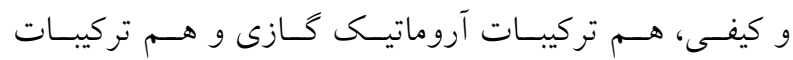

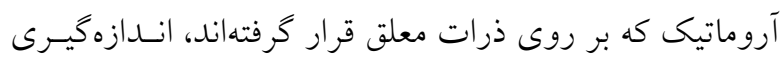

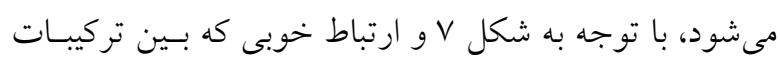

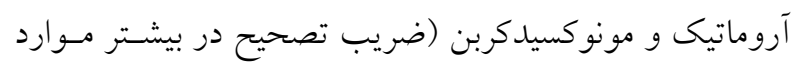

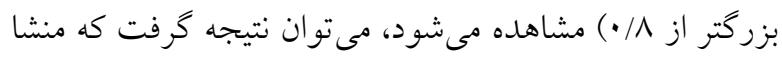

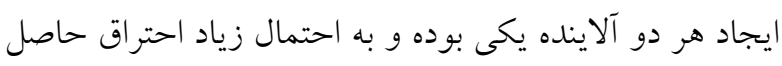

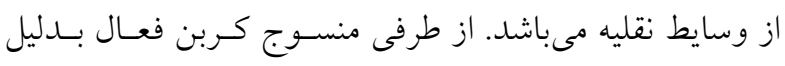

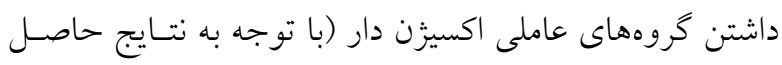

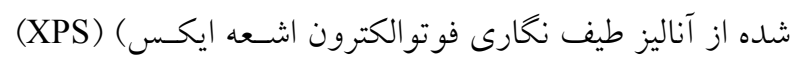

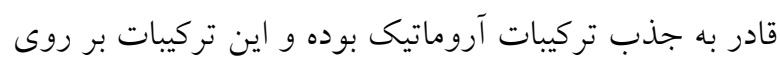

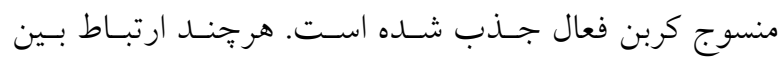

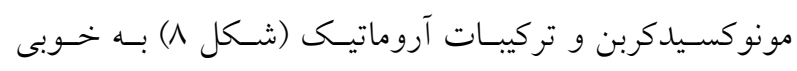
ارتباط مونو كسيدكربن و PM 2.5 نمى باشد كه نشان دهنده ايـن

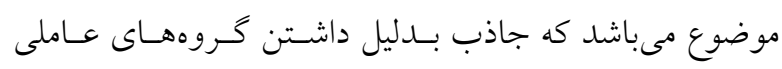

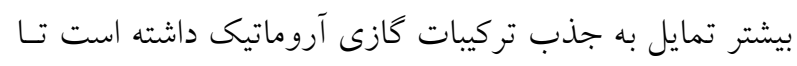
تركيبات آروماتيك كه همراه ذرات معلق بودهاند.

\section{نتيجه گيرى}

هدف از اين تحقيق، استفاده از جاذب منسوج كربن فعـال

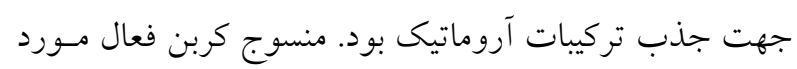

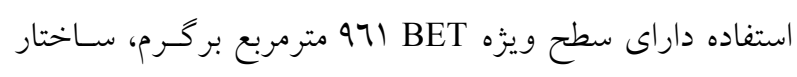

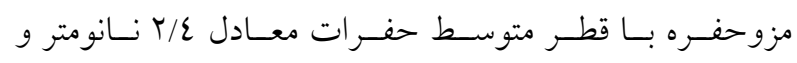

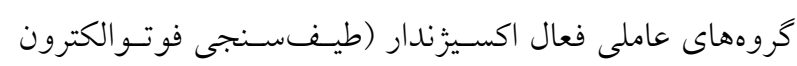

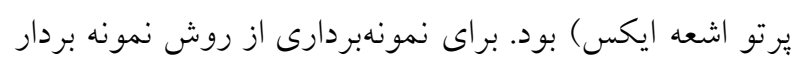

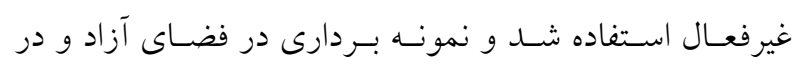

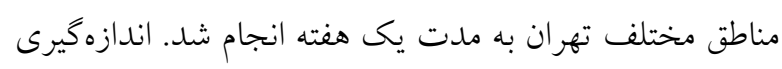

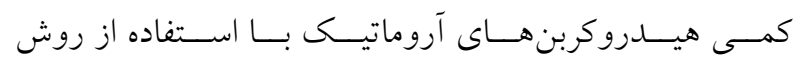

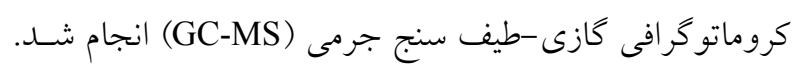
مقادير شاخص آلودخى هوا (ميـزان مونوكسيدكربن و

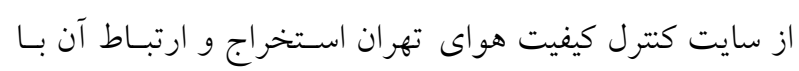

جدول ع، جِيتخر در رتبه ^ (كمترين تعداد خودرو) و ستارى

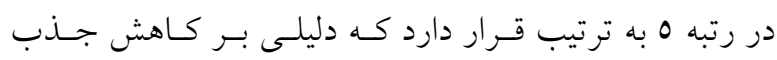

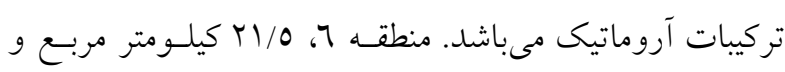

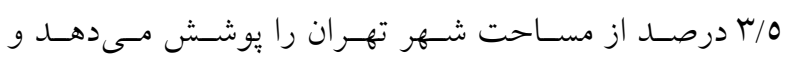

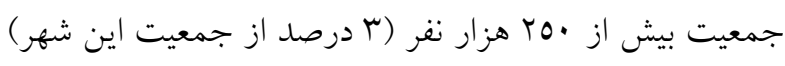

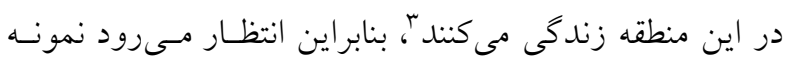

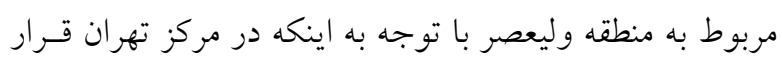
كرفته و از طرفى تعداد خودروهاى عبورى از اين منطقـهـ نيـز

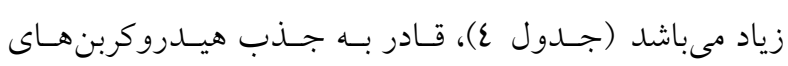

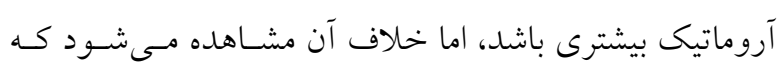

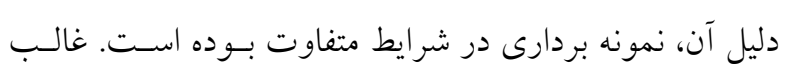

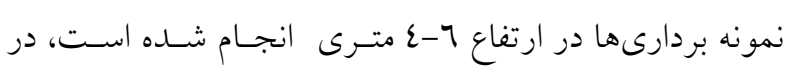

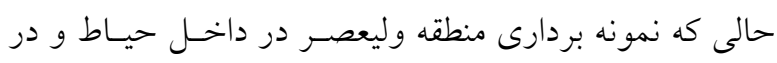

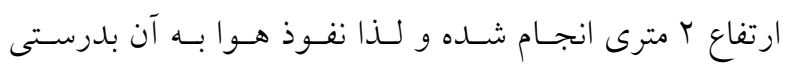

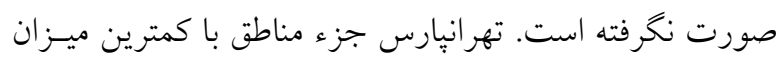

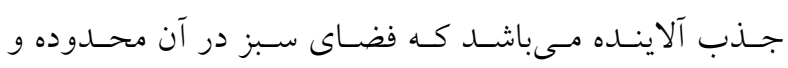

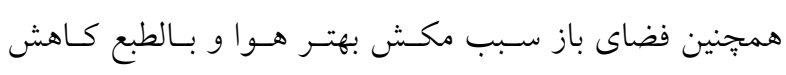

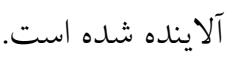

نتايج حاصل از ارتباط دو آلاينده مونوكسيدكربن و

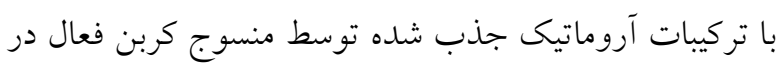

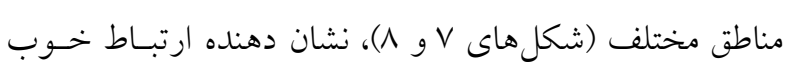

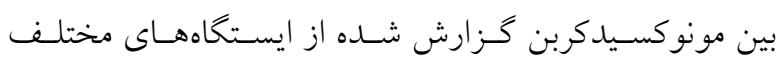

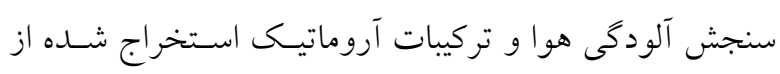

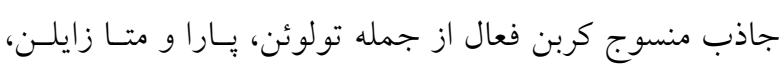

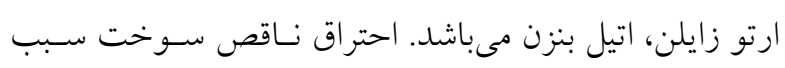

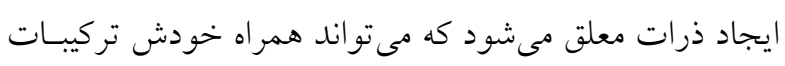

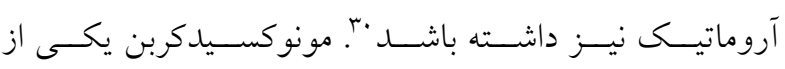

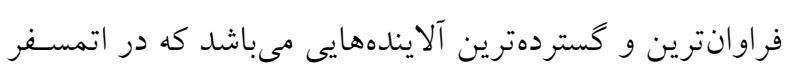

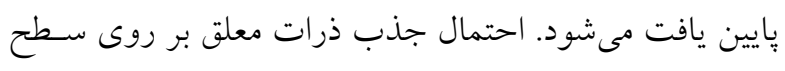

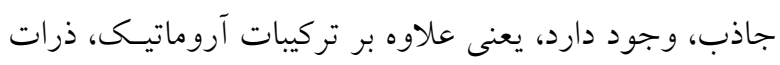
معلق نيز بر روى سطح منسوج كربن فعال مسىنشـيند، هنخـام 


$$
\begin{aligned}
& \text { كاهش ترافيك از وسايل نقلبه عمومى مانــــ متـرو و اتوبـوس } \\
& \text { در خطوط ويزه استفاده گردد. استفاده از بنزين و گازوئيلهاى } \\
& \text { با كيفيت بالاتر ميز باعث كاهش انتشار اين الاينده ها بـه هـوا } \\
& \text { خواهد شد. نتايج حاصل از ايسن تحقيـق نشـان داد كـهـ روش } \\
& \text { نمونه بردارى غيرفعال با استفاده از منسوج كربن فعال روشىى }
\end{aligned}
$$

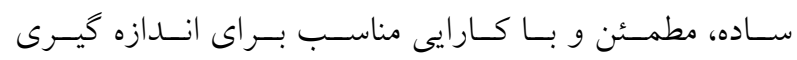

$$
\begin{aligned}
& \text { هيدروكربنهاى آروماتيك درهوا مىباشد. }
\end{aligned}
$$

تقدير و تشكر

اين مقاله حاصل (بخشى از) طـرح تحقيقـاتى حاصـل از

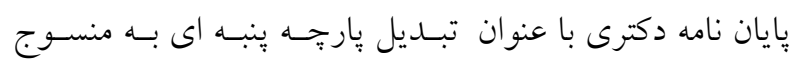
كربن فعال و كاربرد آن در جذب آلاينده هاى بنزن / تولوئن و

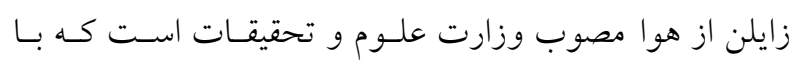
حمايت دانشخاه صنعتى اميركبير اجرا شده است.

\section{References}

1. Esfandani MA, Nematzadeh H. Predicting air pollution in Tehran: Genetic algorithm and back propagation neural network. J Artif Intell Data Min 2016;4(1):49-54.

2. Borhani F, M, Aslemand A. Experimental study of benzene, toluene, ethylbenzene, and xylene (BTEX) contributions in the air pollution of Tehran, Iran. Environ Qual Manag 2017;27(1):83-93 [In Persian].

3. Bandpai AM, Yaghoubi M, Hadei M, Salesi M, Shahsavani A, Hazards O, et al. Concentrations of Criteria Air Pollutants and BTEX in Mehrabad International Airport. J Mazandaran Univ Med Sci 2018;28(160):76-87 [In Persian].

4. Hazrati S, Rostami R, Fazlzadeh M. BTEX in indoor air of waterpipe cafés: Levels and factors influencing their concentrations. Sci Total Environ 2015;524-525:347-53.

5. Davil MF, Naddafi K, Rostami R, Zarei A, Feizizadeh M. A mathematical model for predicting 24 $h$ variations of BTEX concentrations in ambient air of Tehran. Int J Env Health Eng 2013;1(7): 1-6.

6. Atabi F, Mirzahosseini SAH. GIS-based assessment of cancer risk due to benzene in Tehran ambient air. Int $\mathrm{J}$ Occup Med Environ Health 2013;26(5):770-9.

$$
\begin{aligned}
& \text { تركيبات آروواتيكى اندازهيرى شده بررسى شـد. نتـايج نشـان } \\
& \text { داد، جـــاذب مسـتقر در منطقــهـ جواديــه، بيشــرين مقــدار } \\
& \text { هيدروكربنهاى آروماتيك را به خودش جذب كرده و يسس از } \\
& \text { آن منطقه امام خمينى در رده دوم قرار داشت. مهر آبـاد و نظـام } \\
& \text { آباد در رده سوم و جِهارم به ترتيب قرار دارند و يس از آن سه } \\
& \text { منطقـهـ جيتخــر، سـتارى و تهر انِـارس داراى كمتـرين ميـزان }
\end{aligned}
$$

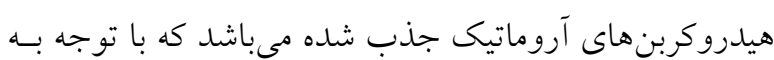

$$
\begin{aligned}
& \text { شرايط توبو گرافى تهران و همجينين تعـداد خـودروى عبـورى }
\end{aligned}
$$

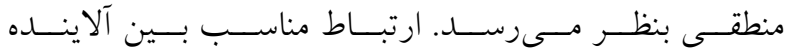

$$
\begin{aligned}
& \text { مونوكسـيدكربن و تركيبـات آروماتيـك جـذب شــده توسـط } \\
& \text { منسوج كـربن فعـال تاييــ كنـــه يكســان بـودن منشـا ايجـاد } \\
& \text { آلايندهها بود كـه احتــاق بنـزين، كازوئيـل و گـاز در موتـور } \\
& \text { وسايط نقليه مىباشد. لذا به منظور كاهش ايسن الاينـده هـا در }
\end{aligned}
$$

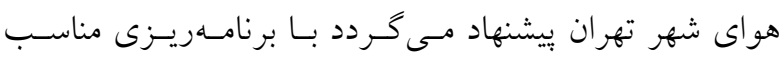

$$
\begin{aligned}
& \text { خودروهاى كهنه و دودزا از جرخه حمل و نقـل شهـر خـارج }
\end{aligned}
$$

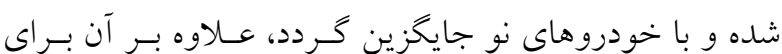

7. Miri M, Rostami Aghdam Shendi M, Ghaffari HR, Ebrahimi Aval H, Ahmadi E, Taban E, et al. Investigation of outdoor BTEX: Concentration, variations, sources, spatial distribution, and risk assessment. Chemosphere 2016;163:601-9.

8. Asadollahfardi G, Mehdinejad M, Mirmohammadi M, et al. Predicting atmospheric concentrations of benzene in the southeast of Tehran using artificial neural network. Asian J Atmos Environ 2015;9(1):12-21.

9. NajafPoor AA, Joneidi Jafari A., Dousti S. Trend analysis of Air Quality Index criteria pollutants $\left(\mathrm{CO}, \mathrm{NO}_{2}, \mathrm{SO}_{2}\right.$, $\mathrm{PM}_{10}$ and $\mathrm{O}_{3}$ ) concentration changes in Tehran metropolis and its relationship with meteorological data, 2001-2009. J Health Field. 2015;3(2). 17-26 [In Persian].

10. Chang T, Ren D, Shen Z, Huang Y, Sun J, Cao J, et al. Indoor air pollution levels in decorated residences and public places over Xi'an, China. Aerosol Air Qual Res 2017;17(9):2197-205.

11. Son HK, Sivakumar S, Rood MJ, Kim BJ. Electrothermal adsorption and desorption of volatile organic compounds on activated carbon fiber cloth. J Hazard Mater 2016;301:27-34. 


$$
\text { راضيه صالحى و همكاران }
$$

12. Mao H, Huang R, Hashisho Z, Wang S, Chen H, Wang $\mathrm{H}$, et al. Adsorption of toluene and acetone vapors on microwave-prepared activated carbon from agricultural residues: Isotherms, kinetics, and thermodynamics studies. Res Chem Intermed 2016;42(4):3359-71.

13. Huang C, Shan W, Xiao H. Recent Advances in Passive Air Sampling of Volatile Organic Compounds. Aerosol Air Qual Res 2018;602-22.

14. Kermani M, Dowlati M, Jafari AJ, Kalantari RR. Health risks attributed to particulate matter of 2.5 microns or less in Tehran air 2005-2014. J Kermanshah Univ Med Sci 2016;20(3):99-105. [In Persian]

15. Davil MF, Rostami R, Zarei A, Feizizadeh M, Mahdavi M, Mohammadi AA, et al. A Survey of 24 Hour Variations of BTEX Concentration in the Ambient Air of Tehran. J Babol Univ Med Sci 2012;14(1):50-55 [In Persian].

16. Sarkhosh M, Mahvi AH, Zare MR, Alavi J, Mohseni M. Assessment of Volatile Organic Compound (VOC) in Tehran Air Pollution in 2010-2011 M.5. J Rafsanjan Univ Med Sci 2013;12(4):271-278 [In Persian].

17. Sadan M, IAmin MM, Karami MA, Teimouri F, Ghasemi R. Comparison between conventional pump and adsorption sampling method with passive solid phase microextraction ( SPME ) sampling to investigate changes in the concentration of benzene, toluene, and xylene ( BTX ) in urban ambient air. J Health Field. 2017;4(4):57-64 [In Persian].

18. Marć M, Tobiszewski M, Zabiegała B, Guardia M de la, Namieśnik J. Current air quality analytics and monitoring: A review. Anal Chim Acta. 2015;853(1):116-26.

19. Du Z, Mo J, Zhang Y, Li X, Xu Q. Evaluation of a new passive sampler using hydrophobic zeolites as adsorbents for exposure measurement of indoor BTX. Anal Methods 2013;5(14):3463-72.

20. Thammakhet C, Villeneuve T, Munisawang V. Monitoring of BTX by passive sampling in Hat Yai Songklanakarin. J Sci Technol 2004;26(1):151-60.
21. Kerchich Y, Kerbachi R, Kerchich Y, Kerbachi R. Measurement of BTEX (benzene, toluene, ethylbenzene, and xylene) levels at urban and semirural areas of Algiers City using passive air samplers. J Air Waste Manag Assoc 2012;62(12): 1370-79.

22. Salehi R, Dadashian F, Abedi M, Hasani B. Optimization of chemical activation of cotton fabrics for activated carbon fabrics production using response surface methodology. J Text Inst 2018;5000:1-9.

23. Rosario L, Pietro M, Francesco SP. Comparative Analyses of Urban Air Quality Monitoring Systems: Passive Sampling and Continuous Monitoring Stations. Energ Procedia 2016;101(2):321-8.

24. Przyjazny A, Kokosa JM. Analytical characteristics of the determination of benzene, toluene, ethylbenzene and xylenes in water by headspace solvent microextraction. J Chromatogr A 2002;977(2):143-53.

25. Nabais JV, Carrott P, Ribeiro Carrott MML, Luz V, Ortiz $\mathrm{AL}$. Influence of preparation conditions in the textural and chemical properties of activated carbons from a novel biomass precursor: The coffee endocarp. Bioresour Technol 2008;99(15):7224-31.

26. Transportation and Traffic Organization of Tehran Municipality.

27. http://airnow.tehran.ir.

28. Shariipour Z, Bidokhti AAA. Investigation of spatial and temporal distributions of air pollutants over Tehran in cold months of 2011-2013. Int J Environ Sci Technol 2005;16(93):133-47. [In Persian].

29. S. Safavi, Alijani B. study of Geographical Factors in Tehran Air Pollution. J Geogr Res 2007;58(2):99-112 [In Persian].

30. Abtahi M, Fakhri Y, Conti GO, Ferrante M, Taghavi M, Tavakoli J, et al. The concentration of BTEX in the air of Tehran: A systematic review-meta analysis and risk assessment. Int J Environ Res Public Health 2018;15(9). $1-16$. 